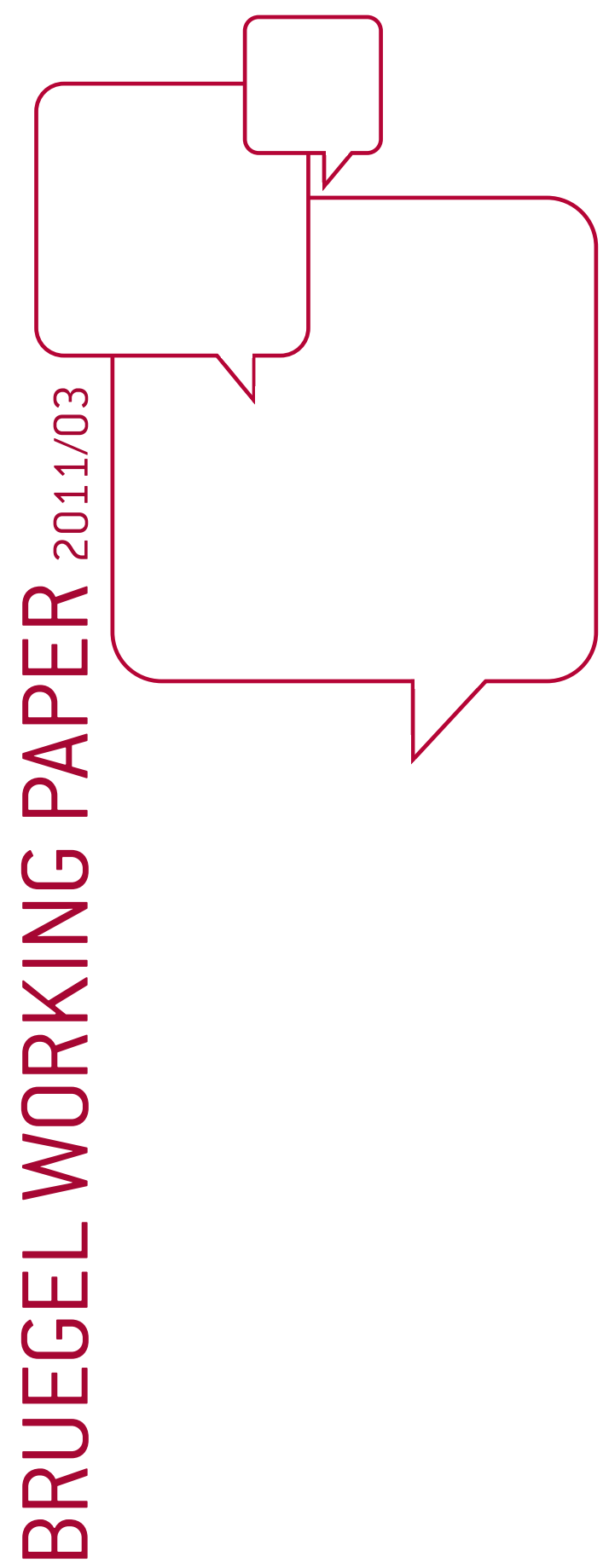

\title{
TOO BIG TO FAIL: THE TRANSATLANTIC DEBATE
}

\author{
MORRIS GOLDSTEIN*AND NICOLAS VÉRON**
}

Highlights

- Although the United States and the European Union were both seriously impacted by the financial crisis of 2007, the resulting policy debates and regulatory responses have differed considerably on the two sides of the Atlantic. In this paper the authors examine the debates on the problem posed by 'too big to fail' financial institutions. They identify variations in historical experiences, financial system structures, and political institutions that help one understand the differences in the approaches of the US, EU member states, and the EU institutions in addressing this problem. The authors then turn to possible remedies and how they may be differentially implemented in America and Europe. They conclude on the policy developments that are likely in the near future.

JEL Codes: G01, G21, G38, F36

Keywords: banks, comparative political economy, financial regulation, microprudential policy, too-big-to-fail

This paper was previously published by the Peterson Institute for International Economics as Working Paper 11-2.

* Senior Fellow at the Peterson Institute for International Economics, mgoldstein@piie.com

** Senior Fellow at Bruegel and visiting fellow at the Peterson Institute for International Economics, n.veron@bruegel.org 
Morris Goldstein has been a senior fellow at the Peterson Institute for International Economics since 1994 and he was the initial holder of the Dennis Weatherstone Chair from 1995 to 2010. He has held several senior staff positions at the International Monetary Fund (1970-94), including deputy director of its Research Department (1987-94). He has written extensively on international economic policy and on international capital markets. He is the author of Managed Floating Plus (2002), The Asian Financial Crisis: Causes, Cures, and Systemic Implications (1998), The Case for an International Banking Standard (1997), The Exchange Rate System and the IMF: A Modest Agenda (1995], coeditor of Debating China's Exchange Rate Policy (2008), Private Capital Flows to Emerging Markets after the Mexican Crisis (1996), coauthor of The Future of China's Exchange Rate Policy (2009), Controlling Currency Mismatches in Emerging Markets (2004), Assessing Financial Vulnerability: An Early Warning System for Emerging Markets (2000), and project director of Safeguarding Prosperity in a Global Financial System: The Future International Financial Architecture (1999).

Nicolas Véron is a senior fellow at Bruegel and, since October 2009, visiting fellow at the Peterson Institute for International Economics. His earlier experience includes both public policy, as a French government official, and corporate finance. He is the coauthor of Smoke \& Mirrors, Inc.: Accounting for Capitalism (2006) and writes a monthly column on European finance for leading newspapers and online media in Belgium, China, France, Germany, Greece, Italy, Russia, and Turkey.

Note: The authors are indebted to Victor Zhikai Gao, Anil Kashyap, and Paul Tucker for their comments at the conference jointly organised by Bruegel and the Peterson Institute with sponsorship by the European Commission on October 8, 2010, where an initial draft of this paper was presented and discussed; to Gonzalo Caprirolo, Gerry Cross, Douglas Elliott, Wilson Ervin, Wim Fonteyne, Mojmír Hampl, Nicolas Jabko, Micol Levi, Sergio Lugaresi, Christian Mouillon, Philippe Peuch-Lestrade, Elliot Posner, Nikhil Rathi, Barbara Ridpath, Jörg Rocholl, and David Westbrook for subsequent feedback on the same draft; to Philip Turner of the Bank for International Settlements for sharing with the authors $\mathrm{BIS}$ data on concentration ratios in banking; and to Allie Bagnall for excellent research assistance. 


\section{INTRODUCTION}

The problem of dealing with too big to fail $\left(\right.$ TBTF $^{1}$ ) financial institutions is not a new one in financial policy, but the severity of the global economic and financial crisis that started in 2007 has put a spotlight on it like never before, along with the size and scope of the measures taken by the official sector to prevent the failure of a host of large and complex financial institutions. This paper aims at reviewing the key dimensions of the policy debate on the TBTF problem, as distinct from other dimensions of discussions aimed at strengthening financial stability, in the two major jurisdictions directly affected by the financial crisis, namely the United States and the European Union. ${ }^{2}$

The TBTF problem gained particular prominence in March 2008 with the controversial rescue of Bear Stearns, when the US Federal Reserve backed JPMorgan Chase's purchase of that ailing investment bank, and then again symmetrically in September 2008 when the US authorities' decision to let Lehman Brothers fail ushered in a sequence of major market disruptions. On October 10, 2008, a few weeks after the Lehman collapse, the finance ministers and central bank governors of G-? countries met in Washington, DC, and "agreed to take decisive action and use all available tools to support systemically important financial institutions and prevent their failure," thus providing official confirmation that the TBTF label was more than just an allegation. A few days later, EU leaders clarified at the October 15-16, 2008, European Council meeting their "commitment that in all circumstances the necessary measures will be taken to preserve the stability of the financial system, to support the major financial institutions, to avoid bankruptcies, and to protect savers' deposits," while adding that "measures to support financial institutions in difficulty should go hand in hand with measures to protect taxpayers, to secure accountability on the part of executives and shareholders, and to protect the legitimate interests of other market players." Given such pledges, it is no wonder that significant attention is being paid by policymakers and analysts alike to how one can avoid a future situation where authorities would once again be faced with an unpalatable binary choice between massive bailouts and market chaos.

The existence of TBTF financial institutions represents a three-fold policy challenge, which we refer to throughout this paper as the 'TBTF problem.'

First, such institutions exacerbate systemic risk by removing incentives to prudently manage risks and by creating a massive contingent liability for governments that, in extreme cases, can threaten their own financial sustainability, with Iceland in 2008-09 and Ireland in 2010 serving as dramatic, recent cases in point. Larger and more diversified banks have shown greater write-downs of assets than smaller and less diversified ones (Haldane, 2010), lending support to the proposition put forward by Stern and Feldman (2004) that large banks 'spend' any diversification cost-saving on greater risk-taking.

Second, TBTF institutions distort competition. According to Moody's, the 50 largest banks in 2009 benefited from an average three-notch advantage in their credit ratings, which has been understood to be at least partly related to official support (BIS, 2010). US banks with assets of more than $\$ 100$

\footnotetext{
1. We use the TBTF shorthand in full awareness of its shortcomings, especially the fact that the systemic importance of financial firms is not dependent on size alone, as we discuss later in this paper. Other shorthand characterizations have been proposed, such as "too important to fail (TITF]," which has become standard at the International Monetary Fund. However, TBTF has acquired sufficiently wide acceptance to be considered a standard way to name our subject matter.

2. Our geographic focus means that some elements of the wider global debate on TBTF, such as the impact of dominant state ownership of large banks in countries such as China, India, or Russia, are not taken up.
} 
billion can fund themselves for more than 70 basis points cheaper than smaller banks. The largest banks have received the lion's share of state intervention: Haldane (2010) reports that 145 global banks with assets over $\$ 100$ billion each accounted for more than 90 percent of the government support since the start of the crisis.

Third, the treatment of TBTF institutions lowers public trust in the fairness of the system and undermines the framework of responsibility and accountability that is supposed to characterise capitalist economies if and indeed when it boils down to the privatisation of gains and socialisation of losses. Johnson and Kwak (2010), among others, regard TBTF institutions as a threat not only to financial stability but to the political fabric as well.

Leading policymakers have often emphasised the importance of TBTF in the context of the financial crisis. Mervyn King (2009), governor of the Bank of England, said in June 2009 that "if some banks are thought to be too big to fail, then ... they are too big.... Privately owned and managed institutions that are too big to fail sit oddly with a market economy." US Federal Deposit Insurance Corporation (FDIC) Chairman Sheila Bair has opined in mid-2009 that the TBTF problem "is at the top of the list of things that need to be fixed... . It fed the crisis, and it has gotten worse because of the crisis" (Cho 2009). US Federal Reserve Chairman Ben Bernanke (2010), testifying before the US Financial Crisis Inquiry Commission, concluded that "if the crisis has a single lesson, it is that the too big to fail problem must be solved." The Irish crisis of November 2010, which led to an official rescue package of $€ 85$ billion, more than 40 percent of which is to be used for immediate bank recapitalisation and contingent support for the banking system, should further increase the prominence of the TBTF problem in European policy debates.

The TBTF problem is reflected in recent trends in concentration of the banking industry. Alessandri and Haldane (2009, p. 28) indicate that the share of the five largest global banks in global banking assets has doubled over the past decade, from 8 percent in 1998 to 16 percent in 2008. Drawing on the The Banker database, International Financial Services London (IFSL, 2010) reports that this increase in concentration has been particularly pronounced during the crisis: with the share of the 10 largest global banks (in the assets of the largest 1,000) rising from 14 percent in 1999, to 19 percent in 2007, to 26 percent in 2009. This trend toward higher concentration also seems to be strongest among the very top banks: the changes in asset share for the next 10 and next 30 largest banks are more modest and different in sign, respectively. The next 10 largest saw their share increase only modestly from 12 percent in 1999 to 15 percent in 2009, with essentially no change between 2007 and 2009. The next 30 saw their share decrease modestly between 1999 and 2009 and more sharply between 2007 and 2009. Using Bank for International Settlements (BIS) data on the ratio of top-three bank assets relative to home-country GDP, we find that the level of concentration was higher in 2009 than in 2006 in 10 out of 14 large, advanced economies. ${ }^{3}$ Whatever the causality, concentration figures suggest that the recent crisis has exacerbated the TBTF problem.

Some policy initiatives have been taken since the start of the crisis to address the TBTF problem, especially through the introduction or reform of special resolution regimes that would provide an alternative to normal insolvency procedures for financial institutions (Goldstein, 2010b). However, there is no consensus that decisions made so far will be sufficient to defang the TBTF problem and this issue is likely to elicit continued policy debates for years to come. Both the difficulty of the problem and its continuing relevance are underlined by the report recently delivered to the G-20

3. The findings are qualitatively similar if one substitutes top-five bank assets for top-three bank assets. 
Summit in Seoul by the Financial Stability Board (FSB, 2010), following difficult international discussions. ${ }^{4}$ Specifically, the Basel III agreement on minimum global capital standards was announced in September 2010 without a consensus on whether to impose a capital surcharge on what the Basel-located bodies call 'systemically important financial institutions' (SIFIs), i.e., those financial firms whose disorderly failure would be likely to create systemwide instability (BCBS, 2010b).

This paper is organised as follows. Sections 2 and 3 look, respectively, at how history and structural differences (in the financial sector) can help to explain current differences in policy orientations between the United States and the European Union on the TBTF issue. Sections 4 and 5 break up the TBTF debate into its two components: the debate on the 'bigness' (size, interconnectedness, and systemic importance) of financial institutions on the one hand, and the debate on how to make the 'failure' of these institutions less costly or disorderly, and ultimately a more credible prospect, on the other. Finally, section 6 offers some brief concluding remarks.

\section{HISTORICAL BACKGROUND, BEFORE AND DURING THE CRISIS}

The United States and European Union have different starting points for the TBTF debate, in part for reasons linked to their respective histories including the experience of the recent crisis. These legacies form a crucial backdrop for any forward-looking policy discussion.

\section{Precrisis history}

The United States has a long tradition of suspicion and concern about large banks, which goes as far back as the controversy between Alexander Hamilton and Thomas Jefferson about the establishment of the First Bank of the United States in 1791. For a long time, the growth of a 'national' financial system was kept in check by initiatives to restrain banking. The 1927 McFadden Act prohibited national banks from opening new branches across state lines. During the Great Depression, the Glass-Steagall Act (1933) forced a strict separation of investment banking activities from depositary banks, leading to the breakup of major institutions, such as the 1935 spinoff of Morgan Stanley from J. P. Morgan \& Co. However, much of this framework was repealed in the 1980s and 1990s. The 1982 Garn-St. Germain Act allowed out-of-state bank-holding companies to acquire failed banks and thrifts, regardless of state law. The Riegle-Neal Act of 1994, which took effect in 1997, largely did away with restrictions on interstate branching for domestic bank holding companies and foreign banks. The Gramm-Leach-Bliley Act of 1999 repealed much of Glass-Steagall and lifted restrictions on the formation of diversified financial conglomerates.

The banking crisis of the 1980s provided a rehearsal for some of the current arguments about the TBTF problem. In 1984, the Continental Illinois National Bank and Trust Company, then the seventhlargest US bank by deposits, ran into severe difficulties and had to be rescued with liquidity support from the Federal Reserve, and with guarantees from the FDIC under a provision of the 1950 Federal Deposit Insurance Act, which had been seldom used until then. In subsequent hearings, the US Comptroller of the Currency admitted that regulators would not let the largest 11 US banks fail (Conover, 1984). The expression 'too big to fail,' at least as applied to banks, is said to date from this episode (Dash, 2009). Partly as a result, the 1991 Federal Deposit Insurance Corporation Improvement Act established a special resolution regime for commercial banks and gave the FDIC a mandate to administer it. However, until 2008 this regime was only applied to relatively small

4. See for example Masters 2010. 
institutions and was therefore not tested on a TBTF institution.

The crisis surrounding Long-Term Capital Management (LTCM), a hedge fund that suffered heavy losses and liquidity tensions as a result of the Asian and Russian financial crises in 1997-98 and had to be bailed out by major banks under the auspices of the Federal Reserve Bank of New York in September 1998, illustrated a new dimension of the TBTF problem - sometimes referred to as 'too interconnected to fail.' With assets in excess of $\$ 100$ billion, LTCM was not huge, but it was felt that its bankruptcy would cause a chain reaction throughout the financial system that could have catastrophic consequences, as assets would have to be liquidated at fire-sale prices.

In the European Union, the historical and political underpinnings of the TBTF problem are very different. Because the continent is composed of independent, generally centralised nation-states with strong cross-border financial linkages, national governments have been encouraged to favour the emergence of a strong and autonomous national financial sector that could successfully compete with its neighbors. Thus, the inclination is generally to protect and foster 'national banking champions.' When these run into difficulties the inclination is to prevent their disappearance or foreign takeover by forcing domestic consolidation or, if this option is not available, by nationalisation.

An early example of such 'financial nationalism' is the creation of Deutsche Bank in 1870 in Berlin, partly to counteract the then dominance of British banks in international transactions, in the context of the formation and rise of the German Empire. As a consequence of the Great Depression and Second World War, large swathes of the financial system were nationalised in several countries, including Italy in 1933 and France in 1946. Since then, privatisations and financial crises (such as those in Spain in the 1980s, or the difficulties of France's Credit Lyonnais in the 1990s) have spurred considerable intracountry consolidation. Somewhat paradoxically, the introduction of the euro as a single currency in much of the European Union first resulted in further intracountry consolidation rather than the cross-border variety, as governments wanted stronger national champions to be ready for what they saw as a forthcoming increase in cross-border competition the main exceptions being within groupings of small like-oriented countries (such as the Benelux or Scandinavia), and the privatisation of the banking sectors of central and eastern European countries.

Since the 1990s, the European Commission has intervened more assertively in the consolidation process than in previous decades. Its Directorate General for Competition (known as DG COMP) has not generally objected to mergers among financial institutions with a cross-border market impact, as the creation of pan-European financial groups was generally seen positively from the perspective of integration of the single European market. ${ }^{5}$ On the contrary, the European Commission has tended to intervene to unblock cross-border combinations that were opposed by national prudential authorities supervising the target firm, particularly since the landmark case of Santander's attempted acquisition of Portugal's Champalimaud Group in 1999. This intervention, combined with the limits reached by intracountry consolidation as some national banking systems became extremely concentrated, encouraged a wave of cross-border banking mergers and acquisitions in the 2000s, which led to the emergence of a handful of truly 'pan-European' groups (such as BNP Paribas, Santander, and UniCredit]. In terms of deal size, the high point of this wave was the ill-fated

5. DG COMP's mandate is only about competition and not about assessing the financial stability impact of mergers and acquisitions, either at national or European level. However, EU legislation allows prudential considerations to be invoked by national authorities to defend a combination that might otherwise be rejected on competition grounds. 
hostile takeover of ABN AMRO in 2007 by a consortium of Royal Bank of Scotland (RBS), Fortis and Santander, which in turn contributed to the downfall of the former two.

Overall, this history has produced a wide diversity of banking structures within the European Union, with the larger continental economies (France, Germany, Italy, the Netherlands, and Spain) still relying predominantly on domestically headquartered banks, and most smaller countries (Belgium, Finland, all former communist countries] dominated by local affiliates of foreign banks. The United Kingdom is a category of its own with, inter alia, one large foreign-owned retail bank (Santander UK), along with very large wholesale activities of nondomestic, European, and non-European financial institutions in the city of London, now the undisputed financial hub of Europe as the continent's capital markets have gradually integrated over the past two decades (a development that has mostly happened independently from banking consolidation).

Apart from the 'domestic champions' mindset, a second major difference between the United States and European Union is the attitude toward bank failures. It is often asserted that the United States is more tolerant of corporate insolvency than most European cultures, and that the US bankruptcy code, at least when applied to nonfinancial companies, is comparatively more protective of corporate executives and employees than most European counterparts. In the case of banking, this difference is compounded in the European (and especially, but not only, in the German) psyche by the memories of the last significant wave of bank defaults in Europe, which in 1931 played a prominent role in enabling the subsequent rise to power of Adolf Hitler's National Socialists. Thus, it is common among European policymakers to see bank failures as politically ominous disasters to be avoided at all costs, even in the case of relatively small banks. In this connection, the head of Germany's financial supervisory authority, BaFin, commented in early August 2007, in the very first stages of the financial crisis, that the bailout of IKB, a second-tier specialised bank that most observers would have thought far smaller than any reasonable TBTF threshold, was necessary to avoid "the worst financial crisis since 1931."

By 'failure' we mean here the case where a financial institution fails to meet its contractual obligations to third parties. In the corporate world, the default process for handling failures is bankruptcy. In banking, and finance more generally, the existence of systemic risk means that bankruptcy can be disruptive much beyond the individual institution that fails. There are essentially three alternatives to bankruptcy when a financial institution reaches the point of insolvency. The first is a specific 'resolution regime' involving the transfer of the institution's assets and economic rights into receivership by a public entity, such as the FDIC in the United States, which can then decide which obligations will be honored or not. The second, nontechnically known as a 'bailout,' is government intervention to repay creditors, which in certain cases is accompanied by nationalisation, i.e., a voluntary or forced transfer of ownership to the state without interrupting business continuity. The third, sometimes euphemistically referred to as 'regulatory forbearance,' is a temporary (sometimes extended) denial by the authorities that the institution is indeed insolvent, if necessary involving the softening or outright exemption of public disclosure requirements (of course, this cannot be considered 'crisis resolution' but only a dilatory measure in the hope that the crisis would disappear or become less acute with the passing of time]. In our use of the word, failure is a possibility under the first of these alternatives to bankruptcy, but not under the latter two.

Using this definition, we are not aware of any single major EU-headquartered bank failing in the first three years of the crisis. ${ }^{6}$ Several banks, such as Northern Rock and Bradford \& Bingley in the United

6. Iceland, which is part of the European Economic Area but not of the European Union, is obviously not included here. 
Kingdom and Hypo Real Estate in Germany, have been nationalised (using newly introduced legislation] and subsequently dismantled, but they have honored all contractual obligations throughout the process, as have Spanish savings banks taken over by the Bank of Spain such as Caja Castilla-La Mancha and CajaSur (using legislation dating from the 1980s). There were some actual bank failures but only of fairly small institutions, such as Weserbank in Germany, which was declared insolvent in April 2008; Dunfermline Building Society in Scotland in March 2009; and DSB Bank in the Netherlands in October 2009. This stands in contrast to Lehman Brothers, Washington Mutual (a major US savings bank that was placed in receivership in late September 2008 and whose banking subsidiaries were subsequently acquired by JPMorgan Chase), CIT Group (a mid-sized commercial finance company that entered bankruptcy in November 2009), and scores of smaller US depositary institutions found insolvent and taken into receivership by the FDIC. Only the funding difficulties of some EU member states may bring significant change. In November 2010, the Irish government decided to impose losses on junior bondholders of Anglo Irish Banks, which had been nationalised in January 2009, and at the time of writing there was expectation of other cases to follow.

A third specific 'European' feature is linked to its welfare and/or social-democrat heritage, namely the importance of cooperatives and savings banks in several EU countries. The United States had a rough equivalent with the savings and loans (S\&L) institutions and credit unions, but their importance and specificity have decreased in the last two decades, not least as a consequence of the S\&L crisis of the 1980s. Many demutualisations and transformations into commercial bank entities have taken place in Italy, Sweden (with the formation of Swedbank), and the United Kingdom, but this segment remains prominent in Austria (Erste, Raiffeisen), Denmark (savings banks), Finland (OP-Pohjola), France (Banques Populaires-Caisses d'Épargne Groupe, Crédit Agricole, Crédit Mutuel), Germany (savings banks and Volksbanken), the Netherlands (Rabobank), and Spain (savings banks). In general, cooperative and savings banks have proved fairly resilient in financial crises, except when they diversified beyond their core retail business in which case they have often run into major difficulties (Fonteyne, 2007). As they are not publicly listed, they typically disclose less financial information than listed peers; this in turn can be a contributing factor to market distrust, as has recently been the case, arguably, in both Germany and Spain.

Outright government ownership of banks used to be widespread but had largely disappeared from the European Union with the large-scale privatisations of the 1980s and 1990s. The main exceptions are Germany's seven Landesbanken, generally jointly owned by local governments (Länder) and local savings banks in varying proportions; ? a few remaining state-owned banks in formerly communist countries, most prominently Poland's largest bank, PKO-BP (51 percent owned by the Polish state as of mid-2009); and specialised national financial institutions with public-service mandates, such as France's Caisse des Dépôts et Consignations, Italy's Cassa Depositi Prestiti, Germany's Kreditanstalt für Wiederaufbau, or Spain's Instituto de Crédito Oficial, which, on most activities, do not compete directly with private-sector financial firms (in the United States, Fannie Mae and Freddie Mac would arguably form a similar category). In addition, of course, there are legacies of government interventions in financial crises, such as the Swedish state's stake in Nordea (19.9 percent as of mid-2009), or more recently the controlling stakes of the UK government in Northern Rock, RBS, and Lloyds Banking Group, and the government ownership of virtually the entire banking sector in Ireland; but in these cases, the respective governments proclaim their intent to sell their shares as soon as market conditions are favourable.

7. For example, BayernLB is 94 percent owned by the state of Bavaria, while Helaba is 85 percent owned by savings banks in the state of Hesse, and Landesbank Berlin is 99 percent owned by the German national association of savings banks (DSGV). 


\section{Developments since 200?}

In the United States, the July 2010 Dodd-Frank Wall Street Reform and Consumer Protection Act (Dodd-Frank Act, 2010) contains a host of provisions targeted at the regulation and supervision of SIFIs (Davis-Polk, 2010), including, inter alia, stipulations that:

- bank holding companies with $\$ 50$ billion or more in assets are automatically subject to enhanced prudential standards;

- once designated, systemically important nonbank financial companies must register with the Federal Reserve within 180 days;

- the Federal Reserve is required to establish enhanced risk-based capital, leverage, and liquidity requirements, overall risk management requirements, resolution plans, credit exposure reporting, concentration limits and prompt corrective action to apply to systemically important bank and nonbank financial firms;

- the enhanced prudential standards will also apply to US operations of foreign bank holding companies, although it is not yet known whether such provisions will apply extraterritorially to the foreign parent;

- $\quad$ subject to some exceptions and a transition period, any 'banking entity' will be prohibited from engaging in proprietary trading or sponsoring and investing in a hedge fund or private equity fund; systemically important nonbank financial companies, while not prohibited from engaging in such activities, will be required to carry additional capital and comply with certain other quantitative limits on such activities (part one of the so-called 'Volcker Rule'); ${ }^{8}$

- any insured depository institution or systemically important nonbank financial company will be prohibited from merging or acquiring substantially all the assets or control of another company if the resulting company's total consolidated liabilities would exceed 10 percent of the aggregate consolidated liabilities of all financial companies at the end of the prior calendar year (part two of the Volcker Rule); and

- systemically important nonbank financial companies and large, interconnected bank companies will be required to prepare and maintain extensive rapid and orderly resolution plans, which must be approved by the Federal Reserve and the FDIC.

Many of these provisions require regulations to be issued by federal agencies, which are still in the works at the time of writing this paper. In a speech in August 2010, the US Treasury secretary continued to underscore the priority attached to making progress on TBTF when he emphasised that "the final area of reform...is perhaps the most important, establishing new rules to constrain risktaking by - and leverage in - the largest global financial institutions" (Geithner, 2010).

By contrast, in the European Union there have so far been no legislative or regulatory initiatives to establish size caps, mandatory capital, or liquidity standards applicable specifically to SIFls, nor anything resembling the Volcker Rule. The only item in the Dodd-Frank 'menu' that has already been met with some action in the European Union is the last one in the list, as various EU member states are asking leading banks to produce proposals to facilitate their possible recovery and/or resolution in a crisis, whether formally as specifically defined 'living wills' or as part of the ongoing supervisory dialogue. In Belgium, recent legislation has created a national systemic risk board that will publish and regularly update an official list of SIFIs requiring special attention: a first version of this list was

8. While this Volcker Rule applies to all banks and is therefore not exclusively targeted at SIFls, it was partly motivated by considerations of systemic risk. 
published in October 2010 and includes 15 legal entities belonging to 9 different financial groups. ${ }^{9}$ In the United Kingdom, the new coalition government elected in May 2010 has established an Independent Commission on Banking that is expected to propose a policy strategy to address the TBTF issue. Its conclusions are expected in June 2011, even though an active public debate will certainly take place before then.

At the European Union level, the legislative response to the crisis has been generally slower than in the United States for four main reasons. First, legislative proceedings are structurally slow in the European Union because of the complex interaction between the EU level and 27 sovereign states.

The lawmaking framework combines the exclusive right of initiative for the European Commission and the need to reach agreement both with the Council of Ministers, which represents the 27 member states voting (in most financial-services matters) under a qualified-majority rule, and with the European Parliament. Second, at the time of the Lehman Brothers collapse, the European Commission was already in lame-duck mode awaiting its planned renewal in 2009 , and this renewal was then further delayed for procedural reasons involving the adoption of the Lisbon Treaty. The new team, including the new commissioner for the internal market and services (who oversees most financial-services issues], Michel Barnier, only took the reins in early 2010. Third, priority was initially given to the necessary overhaul of the European Union's supervisory architecture. This is an innovative policy endeavour that will result in 2011 in the establishment of three supranational European supervisory authorities, with respective mandates over banks (European Banking Authority - EBA), securities and markets (European Securities and Markets Authority - ESMA) and insurance (European Insurance and Occupational Pensions Authority - EIOPA), as well as a European Systemic Risk Board to oversee macroprudential issues. The corresponding legislation, based on a report published in February 2009 (Larosière, 2009), was finalised in September 2010. This rather long delay is unsurprising given the political significance of the changes: the US equivalent is not the limited reorganisation of federal agencies included in the Dodd-Frank Act, but rather the establishment of federal financial authorities such as the Securities and Exchange Commission and the Federal Deposit Insurance Corporation in the 1930s, even though the European agencies will start with a more limited mandate that does not supersede all existing competencies of national supervisors at the level of EU member states. Fourth, and not least, the European Union remains in the midst of an unresolved major banking crisis, while in the United States the 'stress tests' of spring 2009 and subsequent recapitalisation managed to restore a sense of normality at the core of the national banking system, even though many smaller banks have failed since.

Now that a new commission is in charge and a suitable supervisory infrastructure is being put in place, new policy initiatives are to be expected. The indications so far, however, are that the EU institutions are reluctant to envisage specific policies to address the TBTF problem. Two European Commission communications (nonbinding statements of policy principle) were published in 2010, the first on 'Bank Resolution Funds' in May and the second on crisis management and resolution in October (European Commission, 2010a and 2010b). Both contain essentially no reference to a possible differential treatment of SIFls compared to smaller financial institutions, and suggest that the commission at this point remains markedly more cautious on the TBTF problem than the United States has been with the adoption of the Dodd-Frank Act. The same applies to a more recent consultation on 'technical details of a possible EU framework' for bank recovery and resolution

9. Of which five are headquartered in Belgium (Ageas, Dexia, Ethias, Euroclear, KBC) and four are foreign headquartered (AXA, Bank of New York Mellon, BNP Paribas Fortis, ING). Source: Belgian Committee of Risks and Systemic Financial Institutions (CREFS-CSRSFI), Circulaire CREFS 2010-01. 
(European Commission, 2011).

Such caution reflects a more structural challenge for the European Commission as a direct result of the financial crisis. In the preceding decade, the European Union relied on an implicit agreement within both the commission and the European Parliament to foster financial-market integration through the dismantling of national regulatory barriers that hindered it, and thus de facto aligned itself with an international deregulatory agenda (Posner and Véron, 2010). Now that reregulation is the order of the day, this alignment is no longer relevant, and the European Commission finds itself with the need to define a new strategic orientation that must still be compatible with the beguiling diversity of national positions and regulatory cultures within the European Union. One option may be to replicate US choices under the guise of transatlantic convergence, as Commissioner Barnier seems to have chosen in the important issue of moving over-the-counter derivatives toward centralised clearing. However, it is doubtful that the same can be achieved in the highly politically charged area of bank regulation. Thus, it is to be expected that some time will pass before a clear orientation emerges at the EU level in this area.

\section{STRUCTURAL DIFFERENCES BETWEEN THE UNITED STATES AND EUROPEAN UNION}

In this section, we examine the differences in financial and political structures that result from the contrasting historical paths of the United States and European Union. We would argue that such structural differences are influential in shaping the policy arguments on issues such as TBTF.

\section{Financial industry structures}

In the European Union banks play a much bigger role in financial intermediation than in the United States. This contributes to different attitudes toward regulatory reform. The Institute of International Finance (IIF, 2010b) calculates that, as of end-2009, US banks accounted for only 24 percent of credit intermediation in the country, versus 53 percent in Japan and as much as 74 percent in the euro area. Many financial services that in the United States are provided by nonbank financial firms, such as asset management, broker-dealing, and specialised credit functions, are mostly delivered by banking conglomerates in the European Union. To give an illustration: In the Financial Times Global 500 ranking of the world's 500 largest - by market value as of end-June 2010 (latest available) listed companies, all 18 noninsurance financial firms with headquarters in Europe that were listed were referred to as banks, while there were only 7 out of 18 such firms based in the United States (representing 65 percent of the corresponding aggregated market capitalisation ${ }^{10}$ ).

One consequence is that for all the consolidation that has taken place in the United States in recent years, EU-headquartered banks are comparatively larger than their US counterparts, especially when measured by assets. IFSL (2010) research reports that of the worldwide assets of the 1,000 largest banks in 2008-09, EU banks had the largest share at 56 percent versus 13 percent for US banks and 14 percent for Asian banks. Table 1 (on the next page) shows that of the top 25 banks worldwide, ranked by assets at end-2009, 10 of the top 15, including all the 6 largest, hailed from the European Union.

10. The Financial Times list does not refer to Goldman Sachs, Morgan Stanley, and American Express as "banks," even though they have converted to bank holding company status at the height of the crisis in late 2008. If these were considered banks, the share of nonbanks in the sample's aggregate market value would decrease from 35 percent to 19.5 percent. 
Table 1: Top 25 banks worldwide by assets [USD millions] , 1990 and 2009

\begin{tabular}{|c|c|c|c|c|}
\hline \multirow[b]{2}{*}{ Rank } & \multicolumn{2}{|l|}{1990} & \multicolumn{2}{|l|}{2009} \\
\hline & Institution & Assets & Institution & Assets \\
\hline 1 & Dai-ichi Kangyo Bank Ltd., Tokyo & $\$ 428,167$ & The Royal Bank of Scotland, Edinburgh & $\$ 3,500,950$ \\
\hline 2 & Sumitomo Bank Ltd., Osaka & $\$ 409,161$ & Deutsche Bank AG, Frankfurt am Main & $\$ 3,065,307$ \\
\hline 3 & Mitsui Taiyo Kobe Bank, Ltd., Tokyo & $\$ 408,754$ & Barclays Bank PLC, London & $\$ 2,992,682$ \\
\hline 4 & Sanwa Bank Ltd., Osaka & $\$ 402,699$ & BNP Paribas SA, Paris & $\$ 2,888,728$ \\
\hline 5 & Fuji Bank, Ltd. Tokyo & $\$ 399,545$ & HSBC Holdings, London & $\$ 2,418,033$ \\
\hline 6 & Mitsubishi Bank, Ltd., Tokyo & $\$ 391,528$ & Crédit Agricole SA, Paris & $\$ 2,239,370$ \\
\hline$?$ & Crédit Agricole Mutuel, Paris & $\$ 305,206$ & JPMorgan Chase, New York & $\$ 2,175,052$ \\
\hline 8 & Banque Nationale de Paris & $\$ 291,873$ & The Bank of Tokyo-Mitsubishi UFJ Ltd., Tokyo & $\$ 2,025,830$ \\
\hline 9 & Industrial Bank of Japan, Ltd., Tokyo & $\$ 209,067$ & Citigroup, New York & $\$ 1,938,470$ \\
\hline 10 & Crédit Lyonnais, Paris & $\$ 287,331$ & UBS Ag, Zürich & $\$ 1,894,423$ \\
\hline 11 & Deutsche Bank, AG, Frankfurt & $\$ 266,286$ & ING Bank NV, Amsterdam & $\$ 1,853,393$ \\
\hline 12 & Barclays Bank Plc, London & $\$ 258,983$ & Bank of America, Charlotte & $\$ 1,817,943$ \\
\hline 13 & Tokai Bank Ltd., Nagoya & $\$ 249,751$ & Société Générale, Paris La Défense & $\$ 1,572,721$ \\
\hline 14 & Norinchukin Bank, Tokyo & $\$ 249,667$ & Banco Santander SA, Boadilla del Monte & $\$ 1,460,866$ \\
\hline 15 & Mitsubishi Trust \& Banking Corp., Tokyo & $\$ 237,696$ & UniCredit SpA, Milan & $\$ 1,455,270$ \\
\hline 16 & National Westerminster Bank Plc, London & $\$ 232,512$ & Industrial \& Commercial Bank of China, Beijing & $\$ 1,427,685$ \\
\hline 17 & Bank of Tokyo, Ltd. & $\$ 223,185$ & Sumitomo Mitsui Banking Corporation, Tokyo & $\$ 1,219,544$ \\
\hline 18 & Société Générale, Paris & $\$ 219,983$ & China Construction Bank Corporation, Beijing & $\$ 1,105,471$ \\
\hline 19 & Sumitomo Trust and Banking Co., Ltd., Osaka & $\$ 218,916$ & Credit Suisse Group, Zürich & $\$ 1,100,263$ \\
\hline 20 & Mitsui Trust and Banking Co., Ltd., Osaka & $\$ 210,935$ & Agricultural Bank of China Limited, Beijing & $\$ 1,026,300$ \\
\hline 21 & Long-Term Credit Bank of Japan Ltd., Tokyo & $\$ 200,679$ & Bank of China Limited, Beijing & $\$ 1,017,718$ \\
\hline 22 & Dresdner Bank, Frankfurt & $\$ 186,936$ & Mizuho Financial Group, Tokyo & $\$ 1,494,960$ \\
\hline 23 & Union Bank of Switzerland, Zurich & $\$ 183,443$ & Wells Fargo, San Francisco & $\$ 1,309,639$ \\
\hline 24 & Yasuda Trust \& Banking Co. Ltd., Tokyo & $\$ 175,552$ & Bank of Scotland plc, Edinburgh & $\$ 1,005,710$ \\
\hline \multirow[t]{2}{*}{25} & Daiwa Bank, Ltd., Osaka & $\$ 171,239$ & Dexia, Brussels & $\$ 906,063$ \\
\hline & Sum of top 25 & $\$ 6,819,094$ & Sum of top 25 & $\$ 44,912,391$ \\
\hline
\end{tabular}

Source: Goldberg, Jason; American Banker, The Banker Top 1000 World Banks, and Barclays Capital (taken from Barclays Capital "Large-Cap/Mid-Cap Banks 2010 Outlook"] 
Another consequence is that measured in terms of assets to home country GDP, the largest EU banks are much larger, and thus even more likely to be considered TBTF, than their largest US counterparts. As shown in table 2, ratios of top-three or top-five bank assets to GDP show a considerable increase in the size of the largest banks since 1990 (earliest available) in all nine of the large advanced economies included in the sample. As noted earlier, for more than two-thirds of the cases this increase in the size of the largest banks relative to the size of the economy also continued during the recent crisis (where 2006 represents the precrisis observation and 2009 the latest one).

Table 2: Combined assets of the three or five largest banks relative to GDP

\begin{tabular}{|l|c|c|c|c|c|c|}
\hline \multirow{2}{*}{ Country } & \multicolumn{3}{|c|}{ Top 3 banks } & \multicolumn{3}{c|}{ Top 5 banks } \\
\cline { 2 - 7 } & 1990 & 2006 & 2009 & 1990 & 2006 & 2009 \\
\hline Germany & 38 & 117 & 118 & 55 & 161 & 151 \\
\hline UK & 68 & 226 & 336 & 87 & 301 & 466 \\
\hline France & 70 & 212 & 250 & 95 & 277 & 344 \\
\hline Italy & 29 & 110 & 121 & 44 & 127 & 138 \\
\hline Spain & 45 & 155 & 189 & 66 & 179 & 220 \\
\hline Netherlands & 154 & 538 & 406 & 159 & 594 & 464 \\
\hline Sweden & 89 & 254 & 334 & 120 & 312 & 409 \\
\hline Japan & 36 & 76 & 92 & 59 & 96 & 115 \\
\hline US & 8 & 35 & 43 & 11 & 45 & 58 \\
\hline
\end{tabular}

Source: Bank for International Settlements

Just as important for our purposes, table 2 highlights the considerably higher systemic importance of large banks in all major EU economies than in the United States - at least if systemic importance is proxied by the size of the balance sheet, which probably underestimates the importance of banks in the United States given the broader development there of the shadow banking system (Pozsar et al, 2010). Our interpretation is that the TBTF problem is actually much more pressing in the European Union than the United States, but also much more difficult to address. Some might argue that since the European Union has a policy to create a single financial market, bank assets should be compared to the EU GDP rather than the national GDP of the country of headquarters, in which case the EU and US figures would be of a comparable order of magnitude. However, such a comparison of aggregates is less relevant from a policy perspective: As the recent crisis brought home forcefully, de facto public guarantees for most banks come from the home country and only from there, a reality aptly summarised by the quip often attributed to Mervyn King that "international banks are global in life, but national in death." In truth, the European reality is somewhat blurred by some banks' multiple national allegiances. Thus, Dexia was jointly rescued by France and Belgium (and their respective taxpayers) in late September 2008, and it is likely that some burden-sharing would be sought in the case of a public intervention to help, say, Nordea (in this case involving Denmark, Finland, Norway, and Sweden where the group is formally headquartered]. Standard Chartered, while headquartered in the United Kingdom, has much of its activity and also many of its central decisionmaking functions located in Asia, and it is therefore unclear that the UK government would support it even in the event of very serious difficulties. However, even after much cross-border integration, these are exceptional cases and most European banking groups have an unambiguous 'home country' that the current policy framework designates by default as the one whose national government is likely to intervene in a crisis. The same applies to all significant US banks. 
It should be noted that European banks are less globally dominant when ranked by other measures of size or strength. By absolute value of Tier 1 capital (also in 2008-09), US banks dominate the top 10 list: Four of this group are US banks (including the top three), four are EU banks (two from the UK and one each from Spain and France), one is Japanese, and one is Chinese (IFSL, 2010). Rankings by market capitalisation have been dominated since late 2007 by leading Chinese banks, with ICBC consistently at the top and China Construction Bank more often than not number two. ${ }^{11}$ By endSeptember 2010, HSBC (ranked third) was the only 'European' bank in the top five, notwithstanding the fact that much of its activity is in Asia and its chief executive is based in Hong Kong. Santander was the only other European bank in the global top 10, and the smallest of that group, which otherwise includes two other Chinese institutions (Agricultural Bank of China and Bank of China) and four American ones (JPMorgan Chase, Bank of America, Wells Fargo, and Citigroup).

Another major structural difference between the United States and the European Union is the higher degree of internationalisation of European banks, most of which takes place within the European Union. Table 3 (on the next page) illustrates the degree to which European banks have internationalised from their home base to the rest of Europe, less so in the rest of the world. The typical large European bank has less than half its activity in its home country; the corresponding proportion for US banks sampled is above three-fourths.

This difference in the degree of internationalisation implies that cross-border linkages, especially intra-European Union ones, are typically much more important in policy discussions within the European Union than they are in the United States. In a way, one might even say that the discussion on cross-border dimensions of financial stability policy has largely crowded out the one on the TBTF issue in (continental) Europe, at least for the time being.

11. Based on quarterly FT Global 500 rankings, available at www.ft.com. 
Table 3: International versus national sources of bank revenue, large global banks, 2009

\begin{tabular}{|c|c|c|c|c|c|}
\hline \multirow[b]{2}{*}{ EU Banks } & \multirow{2}{*}{$\begin{array}{l}2009 \text { Assets } \\
\text { (US\$ bn) }\end{array}$} & \multicolumn{4}{|c|}{ Estimated share of total 2009 revenue (\%) } \\
\hline & & Home country & Rest of Europe & Americas & Rest of World \\
\hline BNP Paribas & 2.952 & 34 & 42 & 14 & 9 \\
\hline Royal Bank of Scotland & 2.728 & 48 & 27 & 18 & 6 \\
\hline HSBC & 2.356 & 25 & 11 & 34 & 31 \\
\hline Credit Agricole & 2.227 & 49 & 38 & 4 & 8 \\
\hline Barclays & 2.223 & 44 & 15 & 19 & 22 \\
\hline Deutsche Bank & 2.151 & 26 & 41 & 22 & 11 \\
\hline ING & 1.668 & 26 & 24 & 32 & 18 \\
\hline Lloyds & 1.651 & 94 & - & - & 6 \\
\hline Societe Generale & 1.469 & 43 & 39 & 9 & 9 \\
\hline Unicredit & 1.439 & 49 & 41 & n.a. & 10 \\
\hline Santander & 1.439 & 23 & 27 & 50 & n.a. \\
\hline Commerzbank & 1.203 & 84 & 14 & 1 & 0 \\
\hline Intesa Sanpaolo & 878 & 79 & 19 & n.a. & 2 \\
\hline Dexia & 829 & 47 & 43 & 7 & 3 \\
\hline BBVA & 760 & 41 & n.a. & 59 & n.a. \\
\hline Nordea & 729 & 19 & 81 & - & - \\
\hline Danske Bank & 597 & 54 & 40 & - & 6 \\
\hline Standard Chartered & 436 & 6 & 3 & 3 & 88 \\
\hline EU Sample Average & 1.541 & 44 & 28 & 15 & 13 \\
\hline US Banks & 2009 Assets & US (Home) & Rest of Americas & Europe & Rest of World \\
\hline Bank of America & 2.223 & 82 & 1 & 8 & 9 \\
\hline JP Morgan Chase & 2.032 & 75 & 2 & 17 & 6 \\
\hline Citigroup & 1.857 & 32 & 20 & 25 & 23 \\
\hline Wells Fargo & 1.244 & 100 & - & - & - \\
\hline Goldman Sachs & 849 & 56 & n.a. & 26 & 18 \\
\hline Morgan Stanley & 771 & 81 & n.a. & 11 & 9 \\
\hline US Bancorp & 281 & 100 & - & - & - \\
\hline PNC Financial & 270 & 100 & - & - & - \\
\hline Bank of New York & 212 & 47 & n.a. & 37 & 16 \\
\hline BB\& & 166 & 100 & - & - & - \\
\hline US Sample Average & 991 & 77 & 2 & 12 & 8 \\
\hline
\end{tabular}

Source: Forbes rankings, corporate reports, authors' calculations. Mauricio Nakahodo's research assistance is gratefully acknowledged.

\section{Political systems}

A more intangible but no less important factor of transatlantic policy differences is the difference in political systems, which leads to strikingly different decision-making processes and to different allocations of priorities. In most EU countries, the parliamentary nature of the regime means that the executive and legislative branches are closely aligned, while in the United States, divergence between Congress and the Executive branch is typically more frequent. EU countries also vary widely in the respective strengths of the executive and legislative branches, with a rule of thumb that parliaments are generally stronger in Northern than Southern Europe. The United States mainly relies on federal regulation of finance (with some exceptions such as insurance), whereas in Europe competencies in financial and banking regulation are shared between the national and EU levels. Some important matters, such as bankruptcy and tax legislation, are entirely or almost entirely national; others, such as accounting standards for listed companies' consolidated financial statements and oversight of rating agencies, are entirely set at the EU level; and many others are a combination of EU directives (EU-level legislation that requires 'transposition' into national law) and additional national requirements, sometimes referred to in EU jargon as 'gold-plating.' 
Less well-documented is the way the respective political and financial systems interact and depend on each other, a factor that an abundant political science and journalistic literature suggests can be an important driver of policy. In the United States, the attempts of private-sector actors to influence public policy decisions are typically measured in terms of election campaign contributions and lobbying expenses, for which there is a comparatively high degree of public transparency in spite of continuous (and often successful) attempts by private donors to circumvent existing disclosure requirements. For example, Johnson and Kwak (2010) calculate that campaign contributions from the US financial sector have grown from $\$ 61$ million in 1990 to $\$ 260$ million in 2006, a more than fourfold increase. In Europe, no equivalent benchmarks are available. In most EU countries, election campaigns are largely (though not entirely) funded by the public purse, and the granularity of available data on private campaign contributions is inferior to the US equivalent. Lobbying activities tend to be of a more informal nature than in America, and typically go entirely unreported.

That said, numerous examples and anecdotes support the proposition that the financial industry is at least as influential in shaping policy in many parts of Europe as it is in the United States. In Spain and Germany, local politicians sit on savings banks' boards, and regions have direct equity ownership in the Landesbanks. In France, most senior executives in the banking industry have a civil service background, and conversely many prominent civil servants expect to move to banks in their later working years, which may influence their behavior and priorities. In Italy and Belgium, local communities play a significant role in the governance of key financial institutions. In the United Kingdom, city financiers actively engage political leaders in various informal venues. At the EU level, international financial institutions have built considerable influence in recent years, helped by an alignment between their own aims of winning international business and the EU institutions' commitment to cross-border financial integration (Posner and Véron, 2010). It remains to be seen how this relationship is to be affected by the change of emphasis of the European Commission since 2008 toward more intrusive regulation, as a consequence of the financial crisis. The assertive competition policy developed by the European Union since the 1990s illustrates that when no such alignment of aims exists, the European Commission can display a level of imperviousness to corporate influence that is rarely matched by national governments.

Yet another significant dimension is the fact that not all political leaders involved in financial regulation face the same kind of constituencies. In the United States, it is familiar to see Congressional representatives from states with major financial centers taking more favourable views of the financial industry than those without, but no such differences exist within the executive branch as it has a nationwide mandate. In the European Union, however, much of the decisionmaking results from the interaction of member states. Some countries, such as the United Kingdom, host global financial centers; in others, such as Cyprus, Ireland, or Luxembourg, the financial industry is a major contributor to the local economy, while in others still it is not seen as a significant contributor to national competitiveness. Some countries, such as France or Spain, have very limited penetration of foreign banks on their domestic banking markets, but have strong 'national champions' that have dynamically expanded abroad in recent years. Not surprisingly they have repeatedly displayed a strong inclination for home-country regulation, especially in comparison with other countries (such as Finland and most Central and Eastern European member states) where most banks are in foreign hands, and which tend to put more emphasis on host-country control. Differences are especially prominent in matters relative to wholesale financial intermediation, especially those segments that are concentrated in the United Kingdom as a result of several decades of (largely successful) EU financial integration. In such matters, an overwhelming majority of the EU Council of Ministers has no direct political stake in the outcome, as those market 
participants potentially affected are not among their constituents. The discussion of the Alternative Investment Fund Managers (AIFM) directive has been a prominent example of such dynamics. Conversely, the United Kingdom, partly because it hosts the continent's major financial center and its banks have comparatively little activity on the continent, tends to downplay the need for consistent and binding policy frameworks at the EU level. All these specificities tend to make financial policy decision making at the EU level generally more complex, and often less fact based, than it can be in a single, coherent political entity.

\section{THE 'BIGNESS' DEBATE: SIZE, INTERCONNECTEDNESS, AND SYSTEMIC IMPORTANCE}

In a report to G-20 finance ministers and governors, the IMF, BIS, and FSB (2009, p. 2) define systemic risk as "a disruption to financial services that (1) is caused by an impairment to all parts of the financial system, and (2) has the potential to have serious negative consequences for the real economy." SIFls - be they banks or nonbanks - can then be seen as institutions whose impending failure, inability to operate, and disorderly wind-down could produce such systemic effects. ${ }^{12}$ The key criteria most often listed for identifying such SIFIs include size, concentration (sometimes employed as a proxy for substitutability], interconnectedness, performance of systemically important functions, and complexity (which some argue is proxied by the number of majority-owned subsidiaries or affiliates, or by the number of regulatory agencies or courts that would be involved in a resolution of the group). Many analysts also throw in leverage and liquidity as helping to define SIFIs, although these can also be regarded as characteristics of vulnerability that apply to all financial institutions. Most analysts also recognise that TBTF also has a time-dependent or context-dependent dimension, that is, thresholds for TBTF can be much lower if impending failure occurs at a time and/or context in which the economy is fragile and/or other financial institution failures have recently taken place.

To address the challenge posed by TBTF institutions, the first set of proposals concentrates roughly on the notion of 'too big.' This section accordingly explores the options and prospects for regulation of bank size, and their respective implications in the United States and European Union.

\section{Defining bigness}

As suggested above, there is no single measure or single firm characteristic that could provide a simple and straightforward gauge of systemic importance. A flavor of what has been done to gauge what financial institutions are and are not 'systemically important' can be gleaned from the following examples.

The European Central Bank (ECB, 2006, 2007) has published a framework for identifying what it calls large and complex banking groups (LCBGs). It argues that the size of the balance sheet alone may fail to capture important interconnections, especially given the growing importance of offbalance sheet activities. It therefore proposed a multi-indicator approach that incorporates the following 13 variables: assets under custody, contingent liabilities, interbank assets, interbank liabilities, net interest revenue, proceeds from equity issuance, deposits, customer loans, net

12. Thomson (2009, p. 1) argues that a firm is systemically important "if its failure would have economically significant spillover effects [that], if left unchecked, could destabilise the financial system and have a negative impact on the real economy." The ECB (2006, p. 132) argues similarly that large and complex banking groups are those "...whose size and nature of business are such that their failure and inability to operate would most likely spread and have adverse implications for the smooth functioning of financial markets or other financial institutions operating within the system." 
noninterest revenue, proceeds from syndicated loan issuance, other assets, proceeds from bond issuance, and mortgages (ECB, 2006). In ECB (2007). Six more indicators were added to cover cross-border assets, overnight lending contributions, market capitalisation, number of recorded subsidiaries, subordinated debt issuance, and trading income. The indicators were applied to a 2006 sample of 415 euro area and non-euro area banks, and cluster analysis was employed to demarcate the LCBGs from the others. In the end, the ECB (2007) wound up with 36 banking groups that were 'large and complex.' Twenty-one of those were headquartered in the euro area and 15 outside. A composite size measure, based on the 19 indicators, was also constructed for each of these 36 institutions and tests were conducted to see how that measure correlated with total assets (the traditional size measure]. Despite the ECB's (2006) a priori argument that asset size alone was not likely to be a sufficient indicator for indentifying LCBGs, it turned out that the $R^{2}$ between total assets and the composite size measure was about 0.93 , indicating that asset size alone conveys a good deal of useful information.

A second example comes from Thomson (2009), who aimed to establish a set of criteria for designating US financial firms as 'systemically important'. He did not base these criteria on empirical studies but instead used his judgment to suggest measures of size, contagion, correlation, concentration, and conditions and/or context. A sampling from Thomson's criteria conveys the basic idea. His size threshold would be any of the following: 10 percent or more of nationwide banking assets; 5 percent of nationwide banking assets paired with 15 percent or more of nationwide loans; 10 percent of the total number or total value of life insurance products nationwide; and (for nonbank financial firms that were not traditional insurance companies] either total asset holdings large enough to rank it as one of the 10 largest banks in the country or accounting for more than 20 percent of securities underwritten over the past five years. On contagion, a firm would merit designation as systemically important if its failure could result in substantial capital impairment of other institutions accounting for a combined 30 percent of the assets of the financial system or the locking-up or material impairment of essential payments systems. Turning to concentration, Thomson (2009) would regard any financial firm as systemically important if it cleared and settled more than 25 percent of trades in a key financial market, processed more than 25 percent of the daily volume of an essential payments system, or was responsible for more than 30 percent of an important credit activity. However, it is not clear from the article how these thresholds were decided.

Example number three derives from chapter 2 of the April 2009 IMF Global Financial Stability Review (IMF, 2009). The IMF explores four approaches for measuring interconnectedness: (1) network simulations that draw on BIS data on cross-border interbank exposures and that tracks the reverberation of a credit event or liquidity squeeze via direct linkages in the interbank market; (2) a default intensity model that uses data from Moody's Default Risk Service and that measures the probability of failures of a large fraction of financial institutions due to both direct and indirect linkages; (3) a co-risk model that utilises five-year credit default swap (CDS) spreads of financial institutions and that assesses systemic linkages among financial institutions under extreme duress; and (4) a stress-dependence matrix that incorporates individual CDS and probability of default data, along with stock prices, to examine pairs of institutions' probabilities of distress. Among other findings, the IMF (2009) reports that: (1) simulations with the network model confirm that the US and UK banking systems are the most systemic systems in terms of triggering the largest number of contagion rounds and highest capital losses; (2) the Belgian, Dutch, Swedish, and Swiss banking systems are relatively highly vulnerable to banking distress in other economies; (3) if Citigroup's CDS spread were at a very high level (the 95th percentile), this would lead (in a March 2008 simulation] to an increase of 390 percent in AIG's CDS spread but only a 13 percent increase in 
the CDS spread of Wells Fargo; similarly, if Goldman Sachs' CDS spread were at the 95th percentile level during that period, the induced increase in the CDS spread would have been much higher for Bear Stearns than for HSBC or JPMorgan Chase; (4) in March 2008, extreme stress in CDS markets would have had greater spillover effects for 10 other large financial institutions if the stress occurred at HSBC or Commerzbank than if it took place at Wachovia or Bear Stearns; (5) the probability of default of any other bank conditional on Lehman falling into distress went up from 22 percent on July 1, 2007, to 37 percent on September 12, 2008; and (6) drawing on simulations from the default intensity model, the likelihood of the failure of a relatively large number of financial institutions increased sharply during 2008 to exceed the levels seen during the Internet bubble.

Our fourth example deals specifically with complexity. Herring and Carmassi (2010) use the number of majority-owned subsidiaries as a rough proxy for the complexity of a large and complex financial institution (LCFI). They note that the 16 LCFIs identified by the Bank of England (2007) and IMF have 2.5 times as many majority-owned subsidiaries as the 16 largest multinational manufacturing firms. As shown in table 4, taken from Herring and Carmassi (2010, table 8.1, p. 199), such financial conglomerates typically have hundreds of majority-owned subsidiaries; 8 of the 16 LCFls in table 4 have more than 1,000 subsidiaries each and one (Citigroup) has nearly 2,500 of them - half of which are chartered abroad. Lehman Brothers had 433 subsidiaries in 20 countries at the time of its failure. Herring and Carmassi (2010) note that as well as having roughly $\$ 700$ billion in assets, Lehman was the sixth largest counterparty in the over-the-counter (OTC) derivatives market, was a major player in the Repo market, and had among its unsecured creditors the US federal government's Pension Benefit Guarantee Corporation, the German government's deposit insurance arm, and money-market mutual funds, including the Reserve Primary fund, which eventually 'broke the buck.' On top of this, the Fed and Treasury claimed they lacked the tools and/or authority to take over Lehman. Carmassi, Luchetti, and Micossi (2010, p. 59) note that subsidiaries constitute the principal legal form of European cross-border banks, holding assets of almost $€ 4.6$ trillion; subsidiaries of third countries' credit institutions in Europe hold assets of almost $€ 1.3$ trillion. With such complexity for almost all financial conglomerates, it is very difficult to map lines of business into legal entities. Unwinding such complex financial institutions can be a nightmare because SIFls have operations in many countries, because resolution regimes differ (and often conflict) across countries in many respects, because there is no agreement on a cross-border resolution plan, and because the recent crisis demonstrated that national 'ring fencing' of assets is likely to be the default plan when an international bank fails without an agreed burden-sharing formula - an outcome that led some host-country supervisors to press for either an insistence on adequately capitalised subsidiaries or greater say in supervision over foreign banks operating in their backyard (FSA, 2009b). 
Table 4: Large and complex financial institutions

\begin{tabular}{|c|c|c|c|c|c|c|c|c|}
\hline Institution & $\begin{array}{l}\text { Total assets } \\
\text { (USD billion, } \\
\text { year end } \\
2006)^{2}\end{array}$ & $\begin{array}{l}\text { Total sub- } \\
\text { sidaries }^{2}\end{array}$ & $\begin{array}{l}\% \text { of foreign sub- } \\
\text { sidiaries }\end{array}$ & $\begin{array}{l}\% \text { of net foreign } \\
\text { income before } \\
\text { taxes }[2006]^{3}\end{array}$ & $\begin{array}{l}\text { HHI-business } \\
\text { lines revenues } \\
(2006]^{4}\end{array}$ & $\begin{array}{l}\text { Number of } \\
\text { countries }^{5}\end{array}$ & $\begin{array}{l}\text { Subsidiaries in } \\
\text { OFCs, number }\end{array}$ & $\begin{array}{l}\text { Subsidiaries in } \\
\text { OFCs, } \%\end{array}$ \\
\hline UBSAG & 1,964 & 417 & $96 \%$ & $62 \%$ & 2,903 & 41 & 38 & $9 \%$ \\
\hline Barclays PIc & 1,957 & 1,003 & $43 \%$ & $44 \%$ & 2,179 & 73 & 145 & $14 \%$ \\
\hline BNP Paribas & 1,897 & 1,170 & $61 \%$ & $51 \%$ & 1,843 & 58 & 62 & $5 \%$ \\
\hline Citi & 1,884 & 2,435 & $50 \%$ & $44 \%$ & 4,122 & 84 & 309 & $13 \%$ \\
\hline HSBC Holdings Plc & 1,861 & 1,234 & $61 \%$ & $78 \%$ & 3,945 & 47 & 161 & $13 \%$ \\
\hline $\begin{array}{l}\text { The Royal Bank of Scotland } \\
\text { Group Plc }\end{array}$ & 1,711 & 1,161 & $11 \%$ & $34 \%$ & 1,966 & 16 & 73 & $6 \%$ \\
\hline Deutsche Bank AG & 1,483 & 1,954 & $77 \%$ & $80 \%$ & 3,931 & 56 & 391 & $20 \%$ \\
\hline Bank of America Corporation & 1,460 & 1,407 & $28 \%$ & $12 \%$ & 4,256 & 29 & 118 & $8 \%$ \\
\hline JPMorgan Chase \& Co. & 1,352 & 804 & $51 \%$ & $26 \%$ & 2,086 & 36 & 54 & $7 \%$ \\
\hline ABN AMRO Holding NV ${ }^{1}$ & 1,300 & 670 & $63 \%$ & $77 \%$ & 1,381 & 43 & 37 & $6 \%$ \\
\hline Société Générale & 1,260 & 844 & $56 \%$ & $46 \%$ & 4,128 & 60 & 64 & $8 \%$ \\
\hline Morgan Stanley & 1,121 & 1,052 & $47 \%$ & $42 \%$ & 4,476 & 46 & 203 & $19 \%$ \\
\hline Credit Suisse Group & 1,029 & 290 & $93 \%$ & $71 \%$ & 3,868 & 31 & 53 & $18 \%$ \\
\hline Merrill Lynch \& Co., Inc. & 841 & 267 & $64 \%$ & $35 \%$ & 4,089 & 25 & 23 & $9 \%$ \\
\hline Goldman Sachs Group, Inc. & 838 & 371 & $51 \%$ & $48 \%$ & 5,391 & 21 & 29 & $8 \%$ \\
\hline Lehman Brothers Holdings Inc. & 504 & 433 & $45 \%$ & $37 \%$ & 7,807 & 20 & 41 & $9 \%$ \\
\hline
\end{tabular}

Notes:

1. After the most recent list of LCFls (Bank of England, 2007b) was published, a consortium of three banks (RBS, Fortis, and Santander) acquired ABN AMRO

2. Bankscope. Data on subsidiaries refer to majority-owned subsidiaries for which the LFCl is the ultimate owner with a minimum control path of $50.01 \%$

3. Annual reports for each LCFI. Net income before taxes with five exceptions: net income after taxes for Citi, and net revenues for

Barclay Plc, BNP Paribas, Lehman Brothers Holdings Inc., Merrill Lynch \& Co., Inc.

4. Oliver Wyman. The Herfindahlk Hirschman Index ranges from 0 to 10,000 and it is calculated on the percentage of revenues per

business line. Higher values indicate a higher degree of specialization. Lower values imply a higher degree of diversification.

5. Number of countries in which the LCFI has at least one majority-owned subsidiary.

6. Offshore Financial Centers identified by the Financial Stability Forum (2000). We exclude Swiss subsidiaries for Credit Suisse and UBS and Hong Kong subsidi-aries for HSBC. Four subsidiaries were allocated to OFCs on the basis of locations designated in their

names even though Bankscope did not specify a home country.

Source: (Herring and Carmassi, 2010); The Corporate Structure of International Financial Conglomerates: Complexity and its Implications

for Safety and Soundness. 
Our fifth and last example refers to attempts to gather a list of SIFls - presumably based on the kind of criteria outlined above. One attempt was reported in the Financial Times (Jenkins and Davies, 2009), which referred to a list of 24 global banks and 6 global insurance companies that were earmarked for cross-border supervision. The list included six US banks (Goldman Sachs, JPMorgan Chase, Morgan Stanley, Bank of America, Merrill Lynch, and Citigroup), four UK banks (HSBC, Barclays, RBS, and Standard Chartered), one Canadian (Royal Bank of Canada), two Swiss banks (Credit Suisse and UBS), two French banks (Société Générale and BNP Paribas), two Spanish banks (Santander and BBVA), four Japanese banks (Mizuho, Sumitomo Mitsui, Nomura, and Mitsubishi UFJ), two Italian banks (UniCredit and Intesa), one German bank (Deutsche Bank), one Dutch bank (ING), and six European insurance groups (Axa, Aegon, Allianz, Aviva, Zurich, and Swiss Re).

Irrespective of the specific yardstick used to identify SIFIs, one nontrivial policy question is the following: if financial institutions deemed systemically significant are subject to a specific regulatory regime, should this list be made public? Some have argued that going public would undesirably confer official TBTF status on such institutions, thus reinforcing moral hazard. However, it appears unlikely that the identity of firms subject to a specific regulatory treatment can in fact be kept private, especially since such firms would likely be able to challenge their designation as SIFls, including before the fact. Indeed, such a challenge is part of the Dodd-Frank Act of 2010 in the new US financial reform legislation and similar concerns are likely to arise in other countries. Also, as argued above, most large and complex financial institutions already receive in the market a funding discount and credit rating upgrade (relative to smaller financial institutions) that can be at least partly linked to the formers' perceived higher probability of obtaining government support should they get into trouble. Thus, it is not as if the absence of a public SIFI list will eliminate perceptions of unequal bailout treatment. Most importantly, designation as a SIFI is not identical to deeming that institution TBTF; a SIFI can fail if other elements of the regulatory and/or supervisory regime (discussed in the next section) make resolution credible and orderly and do not make liquidation too expensive for the taxpayer. Conversely, the cases of LTCM in 1998 and of IKB and Northern Rock in 2007 suggest that even institutions that would have been unlikely to be included in an official list of SIFIs can be considered too important to be allowed to fail. Indeed, as previously mentioned, Belgium has already proceeded with public disclosure of those firms deemed systemically significant there, including some local affiliates of nondomestic groups, and has done so even before the formal establishment of the public body that will determine which specific regulatory regime such firms should be subject to.

\section{Discouraging bigness through curbs and incentives}

A first set of policy options is to discourage TBTF and to internalise the externalities associated with bigness and complexity through curbs and incentives (as opposed to absolute size limits, which are discussed in the next subsection). We identify three main such options: capital and liquidity surcharges; size-related taxes or levies; and competition policy.

The Basel Committee on Banking Supervision (BCBS), which prepares capital and liquidity standards, has discussed for some time the idea of imposing higher capital (and perhaps also liquidity) requirements on financial institutions deemed systemically important relative to those not so designated. In its September 12, 2010, communication announcing what is commonly known as the Basel III agreement, the Basel Committee referred to this possibility as work in progress, to be decided in coherence with other FSB initiatives, but stated expressly that "systemically important banks should have loss-absorbing capacity beyond the standards announced today" (BCBS, 2010b). 
Here again, one objection to a TBTF capital surcharge is that the financial firms paying such a surcharge will have their TBTF status further enhanced (from de facto to de jure) and that this official designation will provide them with a further unwarranted funding subsidy, thereby exacerbating the misallocation of resources. However, one can doubt how the list of surcharge payers could be very different than the market's existing perceptions of who is and who is not systemically important. Moreover, there is no reason why the surcharge needs to be zero-one; it can be graduated depending on the official sector's evaluation of the size, interconnectivity, and complexity of the individual institution, in which case there is no threshold between non-SIFIs and SIFIs, and no need for a list of SIFIs, public or otherwise. The IMF (2010a) has explored various alternative approaches to estimating the capital surcharge for large and complex financial institutions, which present conceptual similarities to risk-based deposit insurance.

A second approach would be to create disincentives to bigness through tax or tax-like instruments. This would be especially relevant in countries that envisage setting up a new contribution, tax, or levy on financial institutions as a form of compensation for the public support they receive in the event of crises. However, considerations of tax fairness could play a role, at least in some legal environments, and limit the margin for governments to modulate the burden according to size or systemic importance. Those EU countries that have introduced a contribution from the banking industry so far, such as Sweden in 2009, have not decided to include a surcharge for systemic significance. In the United States a financial contribution from the financial industry was proposed by the Obama administration in January 2010 and debated by Congress, but was not included in the final version of the Dodd-Frank Act and remains an open option at this time.

Yet a third approach in this category is to use competition policy to curb the size of the largest financial firms. In the European Union, the European Commission has extensively used its powers since the beginning of the crisis to keep a check on state rescues and on the size of rescued firms. Specifically, it has required firms that received significant support from member states under the cover of safeguarding financial stability, such as RBS, WestLB in Germany, KBC in Belgium, or ING in the Netherlands, to trim the size of their balance sheets and divest important parts of their business portfolios. However, the commission has only acted in cases when the government guarantee has been made explicit, i.e., in a corrective not preventive mode. Nor is it entirely clear at this stage to which extent TBTF concerns could also be applied to EU merger control, leading to block acquisitions or mergers that would exacerbate the TBTF problem, even as applicable EU regulations recognise the legitimacy of prudential and financial-stability considerations in this area. In the United States, it is also unclear how much the domestic competition policy framework would allow similar approaches, especially as, unlike in the European Union, it does not explicitly include control of state aid. As a substitute, the Dodd-Frank Act empowers financial regulators to force a systemically important financial institution to sell activities deemed to contribute to excessive systemic risk. The extent to which this provision will be used in practice remains to be seen.

\section{Prohibiting bigness through size caps and breakups}

A more radical approach than curbing the size of financial institutions is to prohibit, or cap, them from growing beyond a maximum size. The Dodd-Frank Act of 2010 specifies that any insured depository or systemically important nonbank could be prohibited from merging or acquiring substantially all the assets or control of another company if the resulting company's total consolidated liabilities would exceed 10 percent of the aggregate consolidated liabilities of all financial companies. This liability size-cap would not require any existing US financial institutions to shrink, though, and does 
not prohibit their organic growth in the future. It parallels and complements a preexisting cap of 10 percent of total domestic deposits that cannot be exceeded by some forms of external growth, introduced by the Riegle-Neal Interstate Banking and Branching Efficiency Act of 1994.

Some observers have suggested going further, by imposing size limits on systemically important financial institutions relative to GDP. Johnson and Kwak (2010) propose that the size cap for US commercial banks be set at 4 percent of GDP and that for investment banks the cap be set at half that ( 2 percent of GDP). Applied to the present US financial industry structure, this would require the six largest institutions, namely JPMorgan Chase, Bank of America, Citigroup, Wells Fargo, Goldman Sachs, and Morgan Stanley to shrink or split into separate entities. Goldstein (2010a) has favoured size caps for US banks along Johnson-Kwak (2010) lines, although he argues that he could live with somewhat higher caps.

While the size-cap proposal is certainly controversial in the US context, it becomes even more so when viewed in an international environment. As emphasised in the previous section, many European countries have higher levels of banking sector concentration than the United States, and their banks carry comparatively more assets on their balance sheets. As a consequence, a consistent cap set at a few percentage points of GDP would require them to split their prominent banks into myriads of tiny entities. It would also explicitly prohibit small countries from hosting the headquarters of large banks, a proposition that might well generate political and diplomatic tensions.

Conversely, an international uniform size cap that would not depend on national GDP, say a maximum total of assets that banks should not exceed, would be questionable in terms of TBTF avoidance. A cap of $\$ 100$ billion of assets, say, would force many banks in large countries to restructure and splinter drastically. Based on IIF (2010a) calculations, it would require 410 banks to replace the top 20 and 750 banks to replace the top 100 . But it would still be too high to affect TBTF dynamics in most small and mid-sized countries.

At a more fundamental level, substantial disagreement presently exists on the economic cost and benefits that such a size limit would entail.

On the one hand, a longstanding strand of economic literature argues that significant economies of scale exist in banking (Diamond, 1984; Allen, 1990). More recently, studies such as Wheelock and Wilson (2009) find empirical evidence of economies of scale in the US banking sector. Large banks may also play a specifically important role in an internationally integrated financial system. Calomiris (2009) argues that large and complex financial institutions are needed to service large and global nonfinancial businesses. In this view, we would not have the degree of global integration of stock, bond, and foreign exchange markets that we enjoy today without large, global financial firms nor would the flow of finance to emerging economies be what it is with the assorted economic benefits (as discussed, for example, in Cline 2010). Accordingly, so the argument goes, to deny the links between large, global corporations and large, global banks is to ignore both important supplychain links that have transformed the way global firms do business and the globalisation of professional services more broadly, including, for example, law firms and accounting firms. Banks with less than, say, $\$ 100$ billion of assets tend to be mostly domestic in their focus and would not be able to substitute for the cross-border activities of the very large banks. Some relatively highly concentrated banking systems in the advanced world (e.g., Canada and Australia) escaped relatively unscathed from this crisis, while some less concentrated ones (like the United States) incurred relatively high costs. More generally, there is no empirical evidence that banking 
concentration is positively related to the incidence of banking crises; if anything, the evidence goes the other way (Beck, Demirguc-Kunt, and Levine, 2003). Also, foreign bank participation in national banking systems, which often involves comparatively larger financial institutions (Focarelli and Pozzolo, 2001), can be associated with higher financial stability. Persaud (2010) argues that contagion in a systemic financial crisis is an effect more of investor psychology (if firm $A$ has a problem and firm B apparently carries the same type of risk, investors go short on firm B) than actual financial interconnections. Adair Turner, the chairman of the UK Financial Services Authority, has similarly argued recently that "there is a danger that an exclusive focus on institutions that are too big to fail could divert us from more fundamental issues" of precarious credit supply and corresponding macroeconomic volatility (Turner, 2010).

On the other hand, some analysts - such as Johnson and Kwak (2010), Stern and Feldman (2004), Group of Thirty (2009), and Goldstein (2010b) - stress that other empirical studies on the economies of scale in banking finds such economies only for small banks and certainly not beyond $\$ 100$ billion in asset size - to say nothing of the trillion-dollar-plus balance sheets of the world's largest banks (Berger and Mester, 1997; Amel et al, 2004; Herring, 2010). As banks become very large, diseconomies of scale can set in, particularly regarding ability to manage prudently and to implement effective risk-management systems. While the main motive for consolidation is usually described as maximisation of shareholder value, there is also evidence of other motives behind the trend toward larger, more complex financial institutions - such as the desire to avoid taxes and financial regulations, the drive for market power, and the link between firm size and executive compensation - which typically subtract from, rather than add to, social value. In this strand of thought, the defense of universal banks on grounds of diversification and 'economies of scope' across bank products and activities is a false hope. More recent research finds that markets impose a 'discount' on banks when they become more complex - not a diversification premium (Laeven and Levine, 2005). As noted earlier in this paper, measures of bank size and bank diversification have been positively (not negatively) correlated with income volatility during the 2006-08 period. Haldane (2010) finds that larger and more diversified banks have also shown greater write-downs of assets than smaller and less diversified ones. Some authors holding this view also argue that contrary to industry claims, large, complex financial institutions are not needed to service large, global nonfinancial businesses, and that the needs of those businesses can just as well be met by consortia of medium-sized banks without the excess baggage that TBTF institutions bring with them (Goldstein, 2010b; Johnson and Kwak, 2010).

An alternative perspective is to focus not on financial institutions' overall size but on the way critical market functions can become overwhelmingly reliant on a limited number of actors. For example, Tett (2010) notes that the triparty repurchase (or 'repo'] market is predominantly cleared by only two large firms, JPMorgan Chase and Bank of New York Mellon. The systemic importance of that market is such that, as Tett notes, it is impossible to avoid massive moral hazard without a radical change of market structure. More broadly, Giovannini (2010) advocates a separation of all 'infrastructure' functions into separate entities as a way to reduce systemic risk. Such focus on functions that may be deemed incompatible within the same financial group underpins the Volcker Rule, as it did with the Glass-Steagall Act in a different era. However, as this category of approaches does not in principle differentiate institutions according to size, it may not address the TBTF question in a comprehensive way.

Altogether, it is unlikely at this point - for better or worse - that international agreement can be reached on hard size caps for banks. In the United States, aside from the hard size cap on the share of systemwide liabilities that is already in the Dodd-Frank Act and the older cap on deposits, 
regulators will rely on other types of incentives to limit the 'bigness' of financial institutions. Meanwhile, it looks like EU countries will be reluctant to envisage the somewhat disruptive prospect of a mandatory break-up of large banks, given the already mentioned heterogeneity of country preferences linked to diverse structures of national banking markets, and to the perception that prevails there that no sufficiently strong analytical basis is currently available for the assessment of both the costs and benefits of such an option. Softer curbs on the size of financial conglomerates, through a targeted adjustment of prudential, tax, and competition policy, will be insufficient to put an end to the TBTF problem but can at least help to somewhat correct the competitive distortions it creates. In Europe, more cross-border banking integration and centralisation of the supervision of the largest institutions at EU level would allay the current competitive tensions, and would make the TBTF issue less intractable than it currently is in individual EU member states.

\section{THE 'FAILABILITY' ${ }^{13}$ DEBATE: ALLOWING BANKS TO GO UNDER?}

The second class of proposals to address TBTF relates not to the size of institutions, but to the possibility of their failure. If even huge financial conglomerates can fail without creating major market instability, then their bigness becomes less of an inherent problem. The financial crisis, and especially the successive decisions taken by the US authorities on Bear Stearns, Lehman Brothers, and AIG, has illustrated both the difficulties of applying a consistent policy framework to all crisis situations without creating massive moral hazard, and the disadvantages of taking different stances in different cases.

\section{Failure and competition}

It is difficult to separate the debate about the possibility of financial institution failure from a more general conversation about competition in the financial industry, which is made more complex by its multifaceted links with financial stability. Competition simultaneously imposes discipline on financial firms, and can foster excessive risk taking. A bank failure can increase concentration, or on the contrary, provide opportunities for new entrants, depending on how open and competitive the banking system is in which it takes place. In a system where all or most of the financial industry is in government hands, an actual bank failure is virtually impossible and a government bailout is almost guaranteed. $^{14}$

In many EU countries, the financial sector has long been sheltered from competition policy (Carletti and Vives, 2008), and the more assertive stance of the European Commission's Directorate General for Competition (the EU competition authority) since the late 1990s is too recent to have had structural impact in all the European Union's financial systems. Many specific features, even when considered compliant with EU competition policy, restrict the competitive field. For example, German savings banks are generally considered autonomous from one another (see for example in the ECB's statistics of banking concentration in the euro area in ECB, 2010), but the so-called 'regional principle' prevents each of them from proposing or supplying services on another savings bank's territory (they also rely on mutual guarantee schemes at regional and national levels). In other countries such as France, Belgium, or Austria, successive waves of consolidation have led to the almost complete disappearance of independent local banks. There are almost no new entrants in many (Western) European banking markets, in stark contrast to the almost continuous flow of 'de

\footnotetext{
13. For lack of a better word.

14. It is not absolutely guaranteed though, especially at times of major shifts in government policy. Thus, Guangdong International Trust and Investment Company, a large state-owned Chinese bank, declared bankruptcy in January 1999. See Landler 1999.
} 
novo' banks being created at the local level in the United States.

A large sector enquiry carried out by the European Commission between 2005 and 2007 found major competition barriers in many countries in several areas including: payment cards and payment systems, credit registers, product tying, and obstacles to customer mobility (European Commission 2007). Competition issues are also present in US retail financial services, but the large size and relative openness of the national market, near-continuous emergence of new entrants, and provision of many financial services by nonbanks contributes to a generally more competitive playing field than in most EU countries. ${ }^{15}$ In wholesale financial services, the difference is less apparent as indeed many of the most prominent actors are the same on both sides of the Atlantic.

\section{Special resolution regimes}

As mentioned above, special resolution regimes administered by an out-of-court resolution authority appear better adapted to the conditions of financial firms than ordinary corporate bankruptcy processes. As analysed in Cohen and Goldstein (2009), this is primarily because bankruptcy processes pay little attention to third-party effects that are the essence of systemic risk; because creditor stays, and their potential adverse systemic effects, are part and parcel of the bankruptcy process; because bankruptcy proceedings move too slowly to protect the franchise value of the firm; and because bankruptcy does not permit pre-insolvency intervention. However, resolution authority should not be seen as a panacea, if only because it may sometimes be difficult to implement in a way that simultaneously supports market discipline and avoids the contagion effects that financial stability policy is intended to minimise. Supporting market discipline usually is interpreted to mean wiping out shareholders, changing management, and paying off creditors (promptly) at estimated recovery cost (not at par). It may also entail not selling the failing firm to one of the larger players in the field. And it is also increasingly seen as meaning that the resolution authority should be funded in part with ex ante and/or ex post fees on other financial institutions so that the financial sector, rather than the general government budget, pays the lion's share of the costs. However, in some crisis scenarios, policymakers may stray from following through on some of these measures (for example, imposing haircuts to senior bondholders] out of concern that they may precipitate 'runs' on similar instruments in other firms. This appears to have been the case when the EU authorities insisted that the Irish rescue package of November 2010 should not include the imposition of losses on the holders of senior debt issues by Ireland's failed banks. Ultimately, the proof of the pudding will be in the eating.

The US Dodd-Frank Act introduces a new procedure that in effect allows US authorities to apply a special resolution procedure to systemically important nonbank financial institutions, on the initiative of the Secretary of the Treasury and subject to approval of the systemically significant status by a special panel of bankruptcy judges (and of the newly formed Financial System Oversight Council). Once agreed, the resolution procedure would be administered by the FDIC.

In the European Union, the situation varies widely from one country to another but new resolution regimes, for either banks or systemically important financial institutions or both, have been introduced recently or are being introduced through new legislation in Sweden, the United Kingdom, Belgium, and Germany. It is likely that other countries will follow suit in the near future. The idea of

15. In fact, in the US case, one of the most oft-cited concerns about tougher new financial regulations-be they size related or otherwise-is that it will prompt a large (and undesirable) migration of financial activities to the "shadow" banking system. Indeed, for that very reason, some analysts (e.g., Hanson, Kashyap, and Stein, 2010a) have proposed that such regulations be defined on a "product" basis so that they bite equally across the banking and nonbanking sectors. 
an integrated EU bank resolution framework has recently been forcefully endorsed by the IMF (Fonteyne et al, 2010 and Strauss-Kahn, 2010) and by the European Parliament's Committee on Economic and Monetary Affairs, including the specific proposal of a common "European Bank Company Law, to be designed by the end of 2011" (European Parliament, 2010). However, the European Commission has not attempted to harmonise national resolution initiatives so far, let alone create an integrated framework. Even its limited, nonbinding suggestions about the funding of national resolution schemes (European Commission, 2010a) have not been taken on board by several member states. Its latest proposals on crisis management essentially amount to delaying any harmonisation of bank resolution frameworks to after 2012, and any discussion of an EU-level resolution framework to 2014 at the earliest (European Commission, 2010b).

That said, the European Union is playing a role in bank resolution through another channel, namely control of national state aid as part of its competition policy framework. Dewatripont et al (2010) note that under this mandate, the European Commission has effectively contributed to the objectives of mitigation of moral hazard and correction of competitive distortions resulting from national bank bailouts. They advocate a reinforcement of this function, as a complement or substitute for a still-to-be-decided European resolution framework.

\section{Orderly dismantling of complex groups}

The availability of a resolution regime and resolution authority is a necessary condition to envision the orderly resolution of large financial institutions, but it is not sufficient. The resolution authority does not only need the legal powers to intervene, it must also have the operational capability to do so, which can prove to be a significant challenge in itself. The failure of a large financial conglomerate can be a hugely complex affair, especially as corporate structures in the financial sector have become ever more complex, partly as a result of continuous regulatory and tax arbitrage (Herring and Carmassi, 2010].

Since the idea was floated in the UK Turner Review (FSA, 2009b), regulators have pinned hopes on the notion that the financial institutions themselves could meaningfully contribute to alleviating this herculean task. One option is to require each systemically important institution to prepare and maintain a 'living will' or 'wind-down plan' (or, if it also includes provisions aimed at preventing failure in a crisis, a 'recovery and resolution plan'] that would provide regulators with a 'roadmap' to guide them through the maze of subsidiaries, commitments, and contingent liabilities.

In the United States, the Dodd-Frank Act of 2010 stipulates that all systemically important nonbank financial companies and large, interconnected bank companies will be required to prepare and maintain extensive rapid and orderly resolution plans, which must be approved by the Federal Reserve and the FDIC. In cases where the institution is too large and complex to be wound down in a nonsystemic way, the supervisor would have the authority to require the institution to shrink and to become less complex. In several EU countries, the authorities have initiated a dialogue with key financial institutions on resolution options, even if this effort may not always be materialised by a formalised, self-standing plan.

According to Herring (2010), the orderly resolution plans must:

- map lines of business into the corporate entities that would be taken through the resolution process;

- describe the resolution procedures for each entity, along with an estimate of how long each will 
take;

- identify key interconnections across affiliates (such as cross-guarantees, stand-by lines of credit, etc.), along with operational interdependencies (such as information-technology systems);

- contain provisions for developing and maintaining a virtual data room that contains information that the resolution authority would need to expeditiously resolve the entity;

- identify key information systems, where they are located, and the essential personnel to operate them;

- identify any activities or units deemed as systemically relevant and demonstrate how they operate during a wind-down;

- consider how its actions may affect exchanges, clearing houses, custodians, and other important elements of the infrastructure; and

- be updated annually, or more often if a substantial merger or acquisition or restructuring adds extra complexity.

As this list illustrates, the credible maintenance of living wills could represent a significant administrative burden for financial institutions, and there will be trade-offs as to how the requirements will be implemented. The fundamental difficulty is that the resolution strategy is, in many aspects, dependent on the actual features of the crisis in which it would take place. For example, selling certain assets early in the resolution process may depend on whether the markets for these assets remain liquid, which itself is dependent on the specific crisis scenario. As 19th century Prussian General Helmuth von Moltke famously quipped, "no campaign plan survives first contact with the enemy." If orderly resolution plans are very detailed, they might not withstand the first contact with a real crisis. If they stay general and do not provide detail, they might not be able to serve their purpose.

The magnitude of the challenges is compounded by international complexity, which is a common feature of many SIFIs. The Lehman Brothers bankruptcy has illustrated the potential for considerable difficulties to arise from the international interdependencies that must be unwound in the resolution process. While there may be exceptions, this difficulty is in general vastly more pronounced in investment banking than in retail services. As retail operations are local in nature, it can be relatively easy to ring-fence them in a resolution process even if some functions, such as information technology and some aspects of risk management, are provided on a cross-border basis. Global banks with significant retail operations, such as Citi, HSBC, or Santander, often claim that they would be fairly easy to wind up on a country-by-country basis in the event of major financial difficulties - even though this claim is ultimately unverifiable, at least for outside observers, as long as no such process has been tested in real conditions. For investment banks, however, the ability to manage complex and fast-moving cross-border linkages is a core part of the business model and of the value proposition to customers, and for that reason their orderly resolution on a transnational basis is almost by definition a highly problematic endeavour. In effect, there is no relevant precedent. Cross-border banking resolutions have been extremely rare, and generally horribly messy as in the case of Herstatt Bank in 1974, Bank of Commerce and Credit International in 1991, or indeed Lehman Brothers. Conversely, resolutions that have happened in a relatively orderly way, such as, say, Washington Mutual or CajaSur, have generally been largely managed within a single country.

One probably inevitable consequence of the emphasis on resolvability is growing host-country insistence on autonomous capitalisation and funding of local operations for international banks, certainly in retail activities but also, perhaps increasingly, for wholesale business as well. In some 
cases this can take the form of conversion of branches into subsidiaries - especially since the Icelandic crisis brought home the importance of host-country control and protection of local depositors. This will rightly worry advocates of cross-border financial integration, as it may hamper the international intermediation role of financial firms, but the importance of protecting local stakeholders will, in most cases, weigh heavier than concerns about financial fragmentation.

It remains to be seen whether this same concern will be applicable to intra-European Union (or perhaps intra-European Economic Area] activity. On the positive side, there is both a higher degree of commitment to cross-border financial integration and the creation of a single financial market, and there is more of a legal, regulatory and (to some extent) political infrastructure to credibly oversee the financial sector at the supranational level. From this perspective, the creation of the European Banking Authority is probably a step toward a more integrated future supervisory and crisis management framework. In such a framework, we would see a clearer division between financial institutions with a national or local reach, for which supervision shall remain at national level, and 'pan-European' ones, which would be at least partly supervised at the EU level - even as fiscal resources are likely to stay managed by member states for the foreseeable future (Véron 2007). However, as emphasised above, there is not yet a consensus in EU policy circles on such a proposal, and therefore the European Union is bound to retain for an undetermined period of time its current unstable mix of centralised rulemaking, commitment to a single market, and absence of an integrated crisis management and resolution framework.

\section{Making creditors pay: contingent capital and bail-ins}

Another proposal that has caught momentum in the past few months is to envisage mandatory requirements for SIFls to convert a portion of their debts into common equity under prespecified stress conditions (Squam Lake Working Group on Financial Regulation, 2009; Goldman Sachs, 2009; Herring, 2010). At the time of writing, two concepts are widely debated: 'contingent capital' or 'CoCos' for contingent convertible instruments, which have been endorsed in a proposal of the Swiss authorities for additional requirements to Basel III for Swiss-headquartered SIFIs; and 'bail-ins' (Calello and Ervin, 2010), which have been actively discussed within the Basel Committee and FSB (BCBS, 2010a). These ideas have received support from significant financial industry bodies such as the Institute of International Finance (IIF, 2010b) or the Association for Financial Markets in Europe (AFME, 2010). Some have also argued (Goldstein, 2010b) that the minimum global capital standards recently agreed under Basel III (BCBS, 2010b) are too low and that this will increase the need for some type of contingent capital.

In 'bail-ins,' the conversion of specific tranches of debt (in the AFME proposal, preferred stock or unsecured debt] to equity would be decided by regulators, which would require new enabling legislation, as an alternative to resolution. By contrast, in the case of contingent capital, the debt instruments would be automatically converted into equity in application of preexisting contractual arrangements whenever a predefined trigger is reached (somewhat comparable instruments have existed for some time in the insurance industry). Both notions, contingent capital and bail-ins, are seductive as they hold the promise of bringing loss-absorbing equity to financial firms exactly when they need it most, in the midst of a crisis. However, both are also essentially untested. Contingent convertible bonds were issued by Lloyds Banking Group and somewhat similar instruments were issued by the Netherlands' Rabobank, but these precedents are widely seen by market participants as not sufficient to establish the commercial viability of the concept, let alone its effectiveness in crisis conditions. Thus, caution is warranted as to whether these concepts are potentially a way of 'ending too big to fail' (Goldman Sachs, 2009) or merely another hybrid structured finance product 
that may fail its purported objective when tested under stress.

At this stage, it seems prudent to see contingent capital and bail-ins as possible complements to other TBTF antidotes such as capital surcharges for SIFls, special resolution regimes, and orderly wind-down planning, rather than substitutes, and provided they stand the test of the marketplace, which is too soon to assess at the time of writing. ${ }^{16}$

\section{CONCLUDING REMARKS}

In its report for the Seoul Summit in November 2010 (FSB, 2010), the FSB acknowledged the difficulty of addressing the TBTF problem on a transnational basis and recommended a focus of international discussions on what it termed 'global SIFIs' or 'G-SIFIs,' which exclude institutions that are systemically important in a domestic context but have limited international activity (say, Japan Post or the large Chinese banks). This limited agenda underlines the prospect for divergence of practice and implementation in the years ahead, including between the United States and European Union, and to some extent also among EU member states. This need not necessarily be a fatal problem. A global, level playing field in finance is a worthy ideal, but it remains a vision rather than a reality and will remain so for some time. The IMF (2010a) notes that tax rates on the financial sector in advanced economies differ markedly from one another, without resulting in massive moves of financial institutions changing their location in response to these differences. Within the European Union, there is a need for a higher degree of harmonisation, and leaders have committed to the notion of a 'single rulebook,' even if this is unlikely to include tax and bankruptcy arrangements for some time. Elsewhere, regulatory constrains will continue to vary widely, including between both sides of the Atlantic. In a politically heterogeneous world, such variations have to be accepted as a necessary evil.

The adoption of binding 'bigness' caps that would cut SIFls down to a more limited size do not seem likely on either side of the Atlantic, at least in the next few years. In the United States, where hard size caps are viewed perhaps the most favourably, it appears improbable that officials will go beyond the market-share funding caps that are in the Dodd-Frank Act - at least until the more comprehensive approach to deterring TBTF in that legislation has had enough time to be tested. In the European Union, size caps are highly unlikely if measured in terms of assets (or another yardstick) to national GDP. It may be more promising over the longer term to envisage caps defined by size to EU GDP, even though they would not correspond to the current patterns of bank rescues. If this happens, it is likely that such caps would at least initially be set at a relatively high level, comparable to the existing limits applicable to American financial institutions in terms of share of total US deposits and liabilities (10 percent in each case).

There are somewhat higher prospects for change regarding other forms of constraints on the structure of financial conglomerates, namely incompatibilities between certain lines of business corresponding to different types of risk exposures within the same group, akin to the Volcker Rule now adopted in the United States. Giovannini (2010) makes a strong argument for this category of curbs, and we believe an active debate will develop on this issue, not only in the United Kingdom (which has put it on the agenda of its Independent Commission on Banking) but possibly to some extent in the rest of Europe as well, in spite of the dominance of the universal banking model. That said, such functional separation is not about TBTF in a strict sense and is therefore beyond the scope we gave ourselves in this paper.

We also regard the arguments for a comprehensive approach toward discouraging TBTF as

16. See for example Jones 2010. 
compelling enough to expect several initiatives to be adopted in the United States and in several, perhaps all, EU member states. These may include capital surcharges as floated by the Basel Committee, even though they are now fiercely resisted in several parts of the European Union; morethan-proportional levies on large banks, in those countries that would introduce such mandatory contributions; and an assertive conduct of competition policy, at least at the EU level, to put a check on excessive intracountry bank concentration (while still favouring cross-border integration). A transparent designation of SIFls in Europe would have the additional advantage of raising public awareness of the disturbing number of European banks that are indeed systemically important, including most household brand names. This may, in an optimistic view, create incentives for more competition in the European banking sector, a more favourable environment for new entrants, and for more effective cross-border regulatory integration, which would be a way to raise SIFI threshold (if systemic importance is assessed vis-à-vis the EU financial system as a whole, as opposed to national ones).

We underlined why making orderly failure of SIFls a credible prospect is even more difficult in the European Union than it is in the United States; in this connection, it is desirable that all EU countries adopt special resolution regimes and correspondingly empower their financial authorities, which will have the desirable effect of broadening the range of options available to policymakers in future crises. In the mid-term, we expect a resolution authority to be introduced at the EU level, broadly along the lines suggested by the IMF (Fonteyne et al, 2010). In the meantime, resolution authorities should be established or reinforced at national level, and should assertively obtain knowledge on how to unwind the complex structures of SIFls they oversee, in spite of predictable resistance from the financial industry. The most recent working document from the commission at the time of writing (European Commission, 2011) suggests cautious hope that some progress may be made along these lines in 2011-12.

We would, of course, be happier if we could say with a straight face that the TBTF problem was well on its way to being solved on a comprehensive G-20 basis. We cannot say that. But we can say that current policy approaches toward SIFls have taken into account some of the lessons from this global economic and financial crisis, that serious efforts to address the TBTF issue have made their way into legislation in some major economies (more so far in the United States than in the European Union], that there does seem to be a healthy willingness to experiment with different approaches, and that much will depend on whether regulatory authorities will be willing to exercise their newly acquired authority to curb the excesses that turned out to be so costly in the past. Even if these measures do not bring a final solution to the TBTF problem, they are well worth the continued attention of policymakers in the years to come. 


\section{REFERENCES}

AFME (Association for Financial Markets in Europe). 2010. Contingent Capital and Bail-In. London: Association for Financial Markets in Europe (September 22).

Alessandri, Piergiorgio, and Andrew Haldane. 2009. Banking on the State. London: Bank of England (November).

Allen, Franklin. 1990. The market for information and the origin of financial intermediation. Journal of Financial Intermediation 1(1): 3-30.

Amel, Dean, Colleen Barnes, Fabio Panetta, and Carmelo Salleo. 2004. Consolidation and Efficiency in the Financial Sector: A Review of the International Evidence. Journal of Banking and Finance (October).

Bank of England. 2007. Financial Stability Report. London: Bank of England (April).

BCBS (Basel Committee on Banking Supervision). 2010a. Proposal to ensure the loss absorbency of regulatory capital at the point of non-viability. Consultative document (August). Basel: Bank for International Settlements.

BCBS (Basel Committee on Banking Supervision). 2010b. Group of Governors and Heads of Supervision announces higher global minimum capital standards. Basel Committee on Banking Supervision Press Release (September 12).

Beck, Thorsten, Asli Demirguc-Kunt, and Ross Levine. 2003. Bank Concentration and Crises. NBER Working Paper No. 9921. Cambridge, MA: National Bureau of Economic Research (August).

Berger, Allen, and Loretta Mester. 1997. Efficiency and Productivity Change in the US Commercial Banking Industry: A Comparison of the 1980s and 1990s. Federal Reserve Bank of Philadelphia Working Paper No. 97-5. Philadelphia: Federal Reserve Bank of Philadelphia.

Bernanke, Benjamin. 2010. Testimony before the US Financial Crisis Inquiry Commission. Washington.

BIS (Bank for International Settlements). 2010. 80th Annual Report. Basel: Bank for International Settlements (June).

Buehler, Kevin, Hamid Samandari, and Christopher Mazingo. 2009. Capital Ratios and Financial Distress: Lessons from the Crisis. Working Paper No. 15 (December). McKinsey \& Company.

Calello, Paul, and Wilson Ervin. 2010. From bail-out to bail-in. The Economist (January 30).

Calomiris, Charles. 2009. In the World of Banks, Bigger Can Be Better. Wall Street Journal (October 19).

Carletti, Elena, and Xavier Vives. 2008. Regulation and Competition Policy in the Banking Sector. Prepared for the IESE Business School Conference "Fifty years of the Treaty: Assessment and Perspectives of Competition Policy in Europe," Barcelona, November 19-20, 2007. Available at www.cesifo-group.de.

Carmassi, Jacopo, Elisabetta Luchetti, and Stefano Micossi. 2010. Overcoming Too-Big-To-Fail: A Regulatory Framework to Limit Moral Hazard and Free-Riding in the Financial Sector. Brussels: Centre for European Policy Studies. 28).

Cho, David. 2009. Banks "Too Big to Fail" Have Grown Even Bigger. Washington Post (August

Cline, William. 2010. Financial Globalization, Economic Growth, and the Crisis of 2007-09. Washington: Peterson Institute for International Economics.

Coffee, John. 2010. Bail-Ins Versus Bail-Outs: Using Contingent Capital to Mitigate Systemic Risk. Columbia Law and Economic Working Paper No. 380 (September).

Cohen, Rodgin, and Morris Goldstein. 2009. The Case for an Orderly Resolution Regime for Systemically-Important Financial Institutions. Briefing Paper No. 13 (October). Washington: Pew Financial Reform Project, Pew Charitable Trusts.

Conover, Charles. 1984. Hearing Before the Subcommittee on Financial Institutions 
Supervision, Regulation, and Insurance of the Committee on Banking, Finance, and Urban Affairs, Inquiry into the Continental Illinois Corp. and Continental National Bank. US House of Representatives, 98th Congress, 2nd Session, September 18-19 and October 4.

Dash, Eric. 2009. If It's Too Big to Fail, Is It Too Big to Exist? The New York Times (June 20).

Davis-Polk. 2010. Summary of the Dodd-Frank Wall Street Reform and Consumer Protection Act,

Passed by the House of Representatives on June 30, 2010. Washington: Davis-Polk [July).

de Larosière, Jacques. 2009. Report of the High-Level Group on Financial Supervision in the $E U$

(February). Brussels; European Commission. Available at www.ec.europa.eu.

Dewatripont, Mathias, Gregory Nguyen, Peter Praet, and André Sapir. 2010. The Role of State Aid Control in Improving Bank Resolution in Europe. Bruegel Policy Contribution 2010/04 (May).

Diamond, D. W., 1984. Financial Intermediation and Delegated Monitoring. Review of Economic Studies 51, no. 3 (July): 393-414.

Draghi, Mario. 2010. Next steps on the road to financial stability. Financial Times [September 17).

European Central Bank. 2006. Indentifying Large and Complex Banking Groups. Financial Stability Review (December). Frankfurt: European Central Bank.

European Central Bank. 2007. Financial Conditions of Large and Complex Banking Groups. Financial Stability Review (December). Frankfurt: European Central Bank.

European Central Bank. 2010. EU Banking Structures-September 2010. Frankfurt: European Central Bank.

European Commission. 2007. Competition: Commission sector inquiry finds major competition barriers in retail banking. European Commission press release (January 31). Brussels: European Commission.

European Commission. 2010a. Communication on "Bank Resolution Funds" COM(2010) 254 (May). Brussels: European Commission.

European Commission. 2010b. Communication on "An EU Framework for Crisis Management in the Financial Sector" COM(2010) 579 (October). Brussels: European Commission.

European Commission. 2011. DG Internal Market Services Working Document on "Technical Details of a Possible EU Framework for Bank Recovery and Resolution" (January). Brussels: European Commission.

European Parliament. 2010. Report with recommendations to the Commission on Cross-Border Crisis Management in the Banking Sector ECON 2010/2006 (INI) (June28).

Focarelli, D., and A. F. Pozzolo. 2001. The patterns of cross-border bank mergers and shareholdings in the OECD countries. Journal of Banking and Finance 25: 2,305-2,337

Fonteyne, Wim. 2007. Cooperative Banks in Europe-Policy Issues. IMF Working Paper No. 07/159 (July). Washington: International Monetary Fund.

Fonteyne, Wim, Wouter Bossu, Luis Cortavarria-Checkley, Alessandro Giustiniani, Alessandro Gullo, Daniel Hardy, and Sean Kerr. 2010. Crisis Management and Resolution for a European Banking System. IMF Working Paper WP/10/70 (March). Washington: International Monetary Fund.

FSA (Financial Services Authority). 2009a. A Regulatory Response to the Global Banking Crisis.

FSA Discussion Paper 09/2 (March). London: Financial Services Authority.

FSA (Financial Services Authority). 2009b. The Turner Review: A Regulatory Response to the Global Banking Crisis (March). London: Financial Services Authority.

FSB (Financial Stability Board). 2010. Reducing the moral hazard posed by systemically important financial institutions-FSB Recommendations and Time Lines (October). Financial Stability Board.

Geithner, Timothy. 2010. Rebuilding the American Financial System. Speech at NYU Stern School of Business, New York, August 2.

Giovannini, Alberto. 2010. Financial system reform proposals from first principles. Center for 
Economic and Policy Research Policy Insight No. 45 (January). Washington: Center for Economic and Policy Research.

Goldman Sachs. 2009. Ending Too big to fail. Effective Regulation: Part 5 (December). New York: Goldman Sachs Global Markets Institute. Available at www.gs.com.

Goldstein, Morris. 2010a. Confronting Asset Bubbles, Too big to fail, and Beggar-thy-Neighbor Exchange Rate Policies. Peterson Institute for International Economics Policy Brief 10-3 (February). Washington: Peterson Institute for International Economics.

Goldstein, Morris. 2010b. Integrating Reform of Financial Regulation with Reform of the International Monetary System. Paper to be presented at Asian Development Bank-Peterson Institute conference in Seoul, October 2010. Available as unpublished manuscript at Peterson Institute for International Economics, Washington.

Group of Thirty. 2009. A Framework for Financial Stability. New York: Group of Thirty (January).

Haldane, Andrew. 2010. The \$100 Billion Question. Speech to Institute of Regulation and Risk, Hong Kong, March.

Hanson, Samuel, Anil Kashyap, and Jeremy Stein. 2010a. A Macroprudential Approach to Financial Regulation. Journal of Economic Perspectives (forthcoming).

Hanson, Samuel, Anil Kashyap, and Jeremy Stein, 2010b. An Analysis of the Impact of "Substantially Heightened" Capital Requirements for Large Financial Institutions (May, unpublished]. Harvard University and University of Chicago.

Herring, Richard. J. 2010. Wind-Down Plans as an Alternative to Bailouts. Briefing Paper. Washington: Pew Financial Reform Project, Pew Charitable Trusts.

Herring, Richard J., and Jacopo Carmassi. 2010. The Corporate Structure of International Financial Conglomerates: Complexity and its Implications for Safety and Soundness. In The Oxford Handbook of Banking, eds. Allen Berger, Philip Molyneux, and John Wilson. Oxford: Oxford University Press.

IFSL (International Financial Services London Research). 2010. Banking 2010 (February). London: International Financial Services London Research.

IIF (Institute for International Finance). 2010a. Systemic Risk and Systemically Important Firms: An Integrated Approach (May). Washington: Institute for International Finance. Available at www.iif.com.

IIF (Institute for International Finance). 2010b. A Global Approach to Resolving Failing Financial Firms: An Industry Perspective (May). Washington: Institute for International Finance. Available at www.iif.com.

IIF (Institute for International Finance). 2010c. Interim Report on the Cumulative Impact on the Global Economy of Changes in the Banking Regulatory Framework (June). Washington: Institute for International Finance. Available at www.iif.com.

IMF (International Monetary Fund). 2009. Global Financial Stability Report: Responding to the Financial Crisis and Measuring Systemic Risk (April). Washington: International Monetary Fund.

IMF (International Monetary Fund). 2010a. A Fair and Substantial Contribution by the Financial Sector, Interim Report for the G-20 (April). Washington: International Monetary Fund.

IMF (International Monetary Fund). 2010b. Global Financial Stability Report: Meeting New Challenges to Stability and Building a Safer System (April). Washington: International Monetary Fund.

IMF (International Monetary Fund), BIS (Bank for International Settlements), and FSB (Financial Stability Board). 2009. Guidance to Assess the Systemic Importance of Financial Institutions, Markets, and Instruments: Initial Considerations. Report to the G-20 Finance Ministers and Governors (November).

Jenkins, Patrick, and Paul Davies. 2009. Thirty Financial Groups on Systemic Risk List. Financial Times (November 29). 
Johnson, Simon, and James Kwak. 2010. 13 Bankers: The Wall Street Takeover and the Next Financial Meltdown. New York: Pantheon.

Jones, Huw. 2010. Regulators sound caution on bank bail-in proposal. Reuters (October 18).

King, Mervyn. 2009. Speech at the Lord Mayor's Banquet for Bankers and Merchants of the City of London at the Mansion House, London, June 1 ?

Laeven, Luc, and Ross Levine. 2005. Is There a Diversification Discount in Financial Conglomerates? (June). Washington: World Bank.

Landler, Mark. 1999. Bankruptcy the Chinese Way; Foreign Bankers Are Shown to the End of the Line. The New York Times (January 22).

Masters, Brooke. 2010. "Too big to fail" debate still muddled. Financial Times (September 17).

Persaud, Avinash. 2010. Too Big To Fail is No Redemption Song. Vox opinion piece (February 10). Available at www.voxeu.org.

Posner, Elliott, and Nicolas Véron. 2010. The EU and Financial Regulation: Power Without Purpose? Journal of European Public Policy 17 (3): 400-415.

Pozsar, Zoltan, Tobias Adrian, Adam Ashcraft, and Hayley Boesky. Shadow Banking. Federal Reserve Bank of New York Staff Report No. 458 (July).

Reinhart, Carmen, and Kenneth Rogoff. 2009. This Time is Different: Eight Centuries of Financial Folly. Princeton: Princeton University Press.

Rottier, Stéphane, and Nicolas Véron. 2010. Not All Financial Regulation Is Global. Bruegel Policy Brief 2010/0? (September). Also published on www.piie.com.

Squam Lake Working Group on Financial Regulation. 2009. An Expedited Resolution Mechanism for Distressed Financial Firms: Regulatory Hybrid Securities. Council on Foreign Relations (April).

Stern, Gary, and Ron Feldman. 2004. Too Big To Fail: The Hazards of Bank Bailouts. Washington: Brookings Institution.

Strauss-Kahn, Dominique. 2010. Building a Crisis Management Framework for the Single Market. Keynote speech at the European Commission conference, Brussels, March 19.

Tett, Gillian. 2010. Repo needs a backstop to avoid future crises. Financial Times (September 24).

Thomson, James. 2009. On Systemically Important Financial Institutions and Progressive Systemic Risk Migration. Policy Discussion Paper No. 27 (August). Cleveland: Federal Reserve Bank of Cleveland.

Turner, Adair. 2010. Too much "too big to fail? Project Syndicate (September 2].

Véron, Nicolas. 2007. Is Europe Ready for a Major Banking Crisis? Bruegel Policy Brief 2007/03 (August).

Wheelock, David, and Paul Wilson. 2009. Are US Banks too Large? Federal Reserve Bank of St. Louis Working Paper 2009-054B (December).

Wolf, Martin. 2010. Basel: the mouse that did not roar. Financial Times (September 15). 